Revista lus et Praxis, Año 16, No 1, 2010, pp. 3 - 54

ISSN 0717 - 2877

Universidad de Talca - Facultad de Ciencias Jurídicas y Sociales

"Anonimato del progenitor y derecho a la identidad del hijo.

Decisiones judiciales encontradas sobre reserva de identidad en los casos de madre soltera y donante de esperma"

Ramón Durán Rivacoba

\title{
ANONIMATO DEL PROGENITOR Y DERECHO A LA IDENTIDAD DEL HIJO. DECISIONES JUDICIALES ENCONTRADAS SOBRE RESERVA DE IDENTIDAD EN LOS CASOS DE MADRE SOLTERA Y DONANTE DE ESPERMA*
}

\author{
ANONYMITY OF GENETIC PARENTS AND \\ THE CHILDREN'S RIGHT TO KNOW OWN BIOLOGICAL IDENTITY. \\ OPOSSED JUDICIAL DECISIONS ABOUT THE SECRECY OF IDENTITY \\ IN THE CASES OF SINGLE MOTHER AND SPERM DONORS
}

RAMÓN DURÁN RIVACOBA**

\begin{abstract}
RESUMEN
El trabajo discute las soluciones que han dado en España el Tribunal Supremo y el Tribunal Constitucional a casos en los que se ven enfrentados la facultad de mantener el anonimato del progenitor y el derecho del hijo a conocer su identidad biológica.

Se confronta la decisión del Tribunal Supremo de declarar inconstitucionales las normas legales que permiten a la madre no matrimonial resguardar su anonimato, con la sentencia del Tribunal Constitucional, emitida pocos meses antes, que declara constitucionalmente legítimo el anomimato del donante de esperma en el contexto de la aplicación de una técnica de reproducción humana asistida. Se argumenta en contra de ambas soluciones, sobre la base de que en la primera el anonimato materno cumple una función dirigida no directamente a proteger a la madre, sino a proteger al niño frente a un posible aborto o infanticidio por lo que el derecho a la identidad debe ser moderado. Para ilustrar la conveniencia y viabilidad de este razonamiento se hace un amplio análisis del caso "Odièvre" por el que el Tribunal Europeo de Derechos Humanos concluyó que el sistema francés de reserva de la identidad de la madre no era contrario al Convenio Europeo. En cambio, se critica la solución del Tribunal Constitucional sobre el donante de esperma por sobredimensionar el derecho
\end{abstract}

\footnotetext{
* Este trabajo ha sido elaborado gracias a la ayuda prestada por FONDECYT N 1070077/2007, en el marco del Proyecto "Los conflictos de intereses en las relaciones paterno-filiales", correspondiente a la convocatoria "Incentivo a la Cooperación Internacional", dirigido por los profesores Hernán Corral Talciani y María Sara Rodríguez, en la que el autor ejerció como investigador responsable extranjero de contraparte (años 2007-2009). Trabajo recibido el 10 de diciembre de 2009 y aprobado el 25 de marzo de 2010.

** Doctor en Derecho; Catedrático de Derecho Civil y Decano Facultad de Derecho de la Universidad de Oviedo (España). Correo electrónico: rdr@uniovi.es.
} 
a la intimidad del progenitor en desmedro del interés del hijo. La puesta en contraste de estas soluciones permite constatar que la madre, que contaba con medidas de apoyo en concretas situaciones que pudieran poner en riesgo la vida del hijo, las pierde; mientras el padre que, a partir de la reforma del año 1981 que impuso la libertad de investigación de la paternidad, había perdido sus antiguos privilegios, se ve beneficiado de la misma dispensa que ahora se niega para la madre.

\section{ABSTRACT}

The present paper discuss the solutions that Spain's Constitutional Tribunal and Spain's Supreme Court have issued in filiation cases, in which the faculty to the anonymity of genetic parents and the children's right to know own biological identity, appear confronted. We will contrast a decision of the Supreme Tribunal who declared unconstitutional the norms which allow the unwed mother to refuse the child and protect the secrecy of her identity, with the Constitutional Tribunal's decision (issued a few months earlier) which legitimates the anonymity of the sperm donor in the context of an assisted reproduction proceeding. We argue, against both solutions, that in the first one, maternal anonymity seeks not to protect the mother, but to protect the child before a possible abortion or infanticide so the right to the identity must be limited. To illustrate the convenience and viability of this argument we analyze the "Odièvre" case, in which the European Human Rights Court concluded that the French system (that reserves the identity of the mother) was not contrary to the European Covenant. On the other hand, we criticize the Constitutional Tribunal's decision regarding the sperm donor because it overstate the right of privacy of the progenitor against the child's best interest. This contrast exercise shows that the mother, who used to have certain means that could jeopardize the child's life, loses them; however the father (that since 1981 reform that allowed free paternity investigation), benefits with the same dispense that the mother nowadays lack.

PALABRAS CLAVE

Filiación, Derecho a la Identidad, Derecho a la Privacidad

KEY WORDS

Filiation Laws, Right to Know Own Biological Identity, Privacy

\section{Planteamiento: la discriminación Sexista entre los progenitores}

Entre las materias que marcaron mis inicios investigadores destaca el reconocimiento de la filiación' 1 . Esta disciplina, una de cuyas facetas también ocuparía mis primeras publicaciones², acaso implique la parte más técnica del conjunto del Derecho de familia, que reclama, como nunca, una rejuridificación, al encuentro de valores aparentemente perdidos. El todo vale resulta escaso apoyo

\footnotetext{
${ }^{1}$ Cfr. Albaladejo, Manuel, El reconocimiento de la filiación natural, Bosch, Barcelona, 1954.

${ }^{2}$ Cfr. Durán Rivacoba, Ramón, "La eficacia del reconocimiento de la filiación extramatrimonial del menor o incapaz", Anuario de Derecho Civil, 1987, pp. 140 y s.; y DuRÁn RivacoBa, Ramón, "Adopción por los abuelos maternos contra la voluntad del progenitor (Comentario a la Sentencia del Tribunal Supremo de 2 de marzo de 1989)", La Ley III, 1989, pp. 838 y ss.
} 
para el quehacer jurídico. Lo justo corre riesgo de acabar en la esfera de lo arbitrario si se deja expedito el progreso al socaire de la ley del más fuerte, sea en el plano físico, psicológico, económico... Tal creo que constituye uno de los retos cruciales de la disciplina en su presente coyuntura.

Siguiendo esta senda, trato ahora el problema del anonimato del progenitor. Con las perspectivas constitucionales de la filiación en España, era de imaginar derogados viejos esquemas, en los que frente al principio de mater semper certa est se alzaban obstáculos en la investigación de la paternidad, privilegiando sin motivos razonables al varón. El modelo de la férrea familia burguesa no impulsó precisamente la mejora cualitativa del tejido social, aunque tampoco supusiera un límite apreciable a su incremento cuantitativo, como quizás se buscaba. Los antiguos perjuicios que recaían en la descendencia por el comportamiento de los progenitores fueron privados de toda consideración. En una cultura moderna y avanzada, en la que triunfa el axioma de la responsabilidad y, sobre todo, el desagravio a las víctimas inocentes, no había margen para que los padres quedaran exentos de los deberes que acompañan a la generación. La circunstancia obedece a la naturaleza de las cosas: el común alborozo por la nueva criatura se complementa con cargas para los autores, cuya vertiente jurídica mínima garantiza el Derecho, así la provisión de los alimentos necesarios para subsistir o que los derechos sucesorios eventuales no se vean omitidos. Además, ha de reconocerse que las fórmulas superadas tenían un neto cariz sexista, hoy en desuso, al menos en el ámbito de las ideas. El valor emergente de la llamada discriminación positiva no logra, sin embargo, su plausible desarrollo y eficacia. Resulta muy significativo -y lamentable, diría yo- que hasta el año 1990 no viera la luz una ley española sobre igualdad de sexos en el Código Civil.

Es lo cierto que desde la reforma del Código Civil español del año 1981 -o incluso antes, gracias al artículo 39 del texto constitucional, que la preconizaba-, la libre investigación de la paternidad readquiría carta de naturaleza en el acervo jurídico patrio. Ahora bien, a su vez, este principio se ve atemperado si median circunstancias especiales. La verdad biológica sirve como premisa básica, pero no absoluta o excluyente, y cabe advertir algunos supuestos que aconsejan su sabia moderación. En la órbita jurídica no necesariamente se reputa progenitor en cualquier caso al ascendiente carnal. Los ejemplos de los artículos 124 y 125 del Código Civil español son paradigmáticos. El favor filii, o tout pour l'enfant, aminora un fundamentalismo fisiológico, a veces más lesivo que beneficioso. La hipótesis de filiación incestuosa, o aquella en que posibles alternativas familiares, ante la negligencia del padre, pueda ofrecer otras soluciones a quien se hizo cargo de la familia, constituyen su modelo característico.

Sin embargo, en esta materia existen dos variantes novedosas, cuyo relieve no cabe omitir. Los progresos del desarrollo científico hicieron factibles y viables técnicas asistidas de procreación humana, con un amplio abanico de 
supuestos ${ }^{3}$. Mucho me temo que consideraciones casuísticas de piedad ${ }^{4}$ hayan promovido fórmulas abstractas, pero de dudoso acierto conjunto. La carencia de norte seguro en la disciplina con frecuencia distorsiona lo que parecía incólume, al menos teóricamente: la mayor ventaja de los hijos. Todo el ordenamiento exige dicha máxima; por eso se denomina Derecho de filiación y no de paternidad. El injusto panorama de origen, que consentía progenitores indemnes, acaso fomente ahora madres exclusivistas, a espaldas de los prioritarios bienes de la descendencia. Imponer a la prole que nazca sin el amparo de una familia estable no parece muy lógico; y qué decir del reconocimiento de una voluntad materna que omite a uno de los protagonistas básicos del fenómeno, como es el padre. Aunque a ciertas "usuarias" -inaudito término legal (art. 6 Ley de Técnicas de Reproducción Humana Asistida, en adelante LTRHA), máxime cuando se utiliza en imposible masculino por el rótulo de la norma: "usuarios de las técnicas"les resulte superfluo éste, habría que preguntarse por los hijos, destinatarios de semejante deseo exclusivo. A mi juicio, el Derecho no debe acoger impulsos personales, al margen de la justicia colectiva; $y$, especialmente, de los intereses más indefensos. Admitir cuanto las técnicas médicas permitan, configura una praxis de corte neoliberal y anacrónico, según creo mejorable.

A ello se añade la eufemística interrupción voluntaria del embarazo. Lo cierto es que a sus resultas la vida del nasciturus es eliminada ${ }^{5}$. No se menoscaban ya sus derechos o su legítimo futuro, en ocasiones por obra de la naturaleza,

\footnotetext{
${ }^{3}$ Cfr. Anexo de la Ley 14/2006, de 26 de mayo, de Técnicas de Reproducción Humana Asistida.

${ }^{4}$ Según afirma el inicio de la Exposición de Motivos de la Ley, "la aparición de las técnicas de reproducción asistida en la década de los 70 supuso la apertura de nuevas posibilidades de solución del problema de la esterilidad para un amplio número de parejas aquejadas por esta patología. La novedad y utilidad de estas técnicas hicieron sentir muy pronto en los países de nuestro entorno la necesidad de abordar su regulación".

${ }^{5}$ La Sentencia del Tribunal Constitucional español de 11 de abril de 1985 trató del recurso previo de inconstitucionalidad del Proyecto de Ley sobre despenalización del aborto, cuya elocuente doctrina me gustaría recoger aquí: el "derecho a la vida, reconocido y garantizado en su doble significación física y moral por el artículo 15 de la Constitución, es la proyección de un valor superior del ordenamiento jurídico constitucional -la vida humana- y constituye el derecho fundamental esencial y troncal en cuanto es el supuesto ontológico sin el que los restantes derechos no tendrían existencia posible". "La vida humana es un devenir, un proceso que comienza con la gestación, en el curso de la cual una realidad biológica va tomando corpórea y sensitivamente configuración humana, y que termina en la muerte; es un continuo sometido por efectos del tiempo a cambios cualitativos de naturaleza somática y psíquica que tienen un reflejo en el status jurídico público y privado del sujeto vital". "La gestación ha generado un tertium existencialmente distinto de la madre, aunque alojado en el seno de ésta". "La vida del nasciturus, en cuanto éste encarna un valor fundamental -la vida humana- garantizado en el artículo 15 de la Constitución, constituye un bien jurídico cuya protección encuentra en dicho precepto fundamento constitucional". "Esta protección que la Constitución dispensa al nasciturus implica para el Estado con carácter general dos obligaciones: la de abstenerse de interrumpir o de obstaculizar el proceso natural de gestación, y la de establecer un sistema legal para la defensa de la vida que suponga una protección efectiva de la misma y que, dado el carácter fundamental de la vida, incluya también, como última garantía, las normas penales". "El Estado tiene la obligación de garantizar la vida, incluida la del nasciturus (art. 15 de la Constitución), mediante un sistema legal que suponga una protección efectiva de la misma". La simple lectura de los votos particulares contrarios a la tesis mayoritaria es bien expresiva de cuanto afirma dicha sentencia y su sentido, que se corre riesgo de olvidar.
} 
sino que su mismo existir queda frustrado a causa de la intervención agresiva del hombre, a menudo con dudosa cobertura legal. Por eso, los mecanismos jurídicos que puedan arbitrarse para eludir este resultado deben merecer la máxima consideración.

La mezcla de tales fenómenos produce consecuencias distorsionadoras en la filiación y su régimen. Ambos son recursos artificiales de signo contrario, en la medida en que uno promueve y el otro evita nacimientos de nuevas personas, aunque con frecuencia tengan análogo alcance destructivo sobre la vida humana. En el plano jurídico sus distancias se incrementan. Las técnicas que requieran auxilio ajeno en forma de donación del esperma fecundante para la mujer, impulsan de suyo el desconocimiento de la filiación biológica (cfr. art. 5 LTRHA), pues para eso sirve (cfr. art. 8 LTRHA). Resulta una verdadera paradoja que a través de una especie de dogma biológico terminen por impedirse las consecuencias naturales de los vínculos de parentesco, pero así es. El anonimato que se propugna quiebra de raíz las bases del Derecho de filiación y hace ilusorio el propósito legalmente confesado de que se determine con arreglo al sistema general establecido en el Código Civil (cfr. art. 7 LTRHA). No es fácil asistir a un episodio tan acabado de lo políticamente correcto, al margen de su falacia intrínseca; y eso sin reparar en que sólo es masculino el anonimato. Mientras, la donación de óvulos se obsta y, si aconteciera, la gestante sería también madre jurídica (cfr art. 10 LTRHA). Curiosa doble vara de medir discriminatoria, máxime si la experiencia enseña que no siempre dicha práctica se guía por el altruismo ${ }^{6}$. Cuando se pretenden recoger sutilezas en un panorama marcado por la desmesura la conclusión final se aproxima mucho al ridículo.

En el otro fiel de la balanza se sitúa un dato que, según creo, encontraría motivos de aquiescencia. Permitir el aborto, sea en mayor o menor alcance, supone acoger agresiones selectivas, por mucho que logren respaldo jurídico. En el conjunto del proceso, hay dos intervinientes que reclaman defensa; la madre por necesidad, y el hijo por justicia?. Ambos son protagonistas de un drama merecedor de las actitudes más solidarias y generalizadas posibles, pero, a su vez, el ordenamiento ha de asumir cuantas iniciativas estén a su alcance para rebajar su incidencia. Condiciones personales extremas en la mujer $-\mathrm{y}$ no me limito a las penurias económicas- demandan un prudente desarrollo de alternativas para el cuidado de hijos que no puedan recibir las atenciones maternas. Hay que agotar todos los recursos imaginables antes de poner en peligro la nueva vida.

\footnotetext{
${ }^{6}$ La Ley sobre fecundación artificial defiende, con muy escaso perfil jurídico, que "la donación nunca tendrá carácter lucrativo o comercial" (art. 5.3 LTRHA). En su categoría técnica, las liberalidades son modelos de actos lucrativos, aunque se predique, no de su autor, sino del destinatario.
}

${ }^{7}$ Excede aquí el interesante problema sobre los derechos del padre a ser, por lo menos, consultado acerca de la cuestión. 
Asumía una concreta forma el Reglamento del Registro Civil, autorizando a la madre acuciada en dichos casos difíciles a desconocer la filiación. Sin embargo, el Tribunal Supremo impide su vigencia, por contravenir sobrevenidamente lo dispuesto en la Constitución española. Meses antes, el Tribunal Constitucional auspició el anonimato de quien done su esperma en la fecundación asistida y engendre así un hijo. El simple contraste de ambas medidas Ilena de asombro. Cada una obedece a circunstancias particulares, pero solapadas siembran de dudas su acierto. Más bien indica el desorden que oscurece la materia y, desde luego, pone de relieve que antiguas discriminaciones se perpetúan bajo apariencias constitucionales.

El propósito de mi sucinto estudio se dirige a debatir el supuesto, máxime si existen poderosos indicios que manifiestan lo endeble de las soluciones adoptadas. Mas antes desearía recoger una última consideración preliminar. Las relaciones entre padres e hijos son bilaterales, pero no equidistantes. Constituye un vínculo tan específico que incluso diferencia en la práctica el sexo de los progenitores. Eso es un hecho social incontestable, muchas veces recogido en los ordenamientos jurídicos, que, salvo circunstancia obstativa, prefieren mantener a la prole con la madre si los padres no viven juntos. Las Partidas lo establecían durante los tres primeros años, merced a una especie de presupuesto nutricio, luego elevado en el Código Civil español a los siete años por razones educativas de primer desarrollo de la criatura. Discutibles motivos de igualdad jurídica eliminaron esta preferencia teórica en la reforma del año 1990, si bien la práctica mantiene, como no podía ser de otra manera, su vigencia. Los nexos biológicos y naturales entre la madre y su descendencia son generalmente más intensos que los del padre. Igualmente, las relaciones entre los progenitores y sus hijos alcanzan cotas superiores a los que dicta el matrimonio. Por eso la prole desplaza en la herencia por cualquier título al cónyuge. A su vez, la unión de los padres respecto de sus hijos resulta superior que a la inversa. Gracias a ello, los propios hijos sustituyen a los ascendientes en su sucesión. Estos datos obedecen a hechos que no pueden omitirse, y discutir su implantación jurídica produce distorsiones notorias, uno de cuyos paradigmas constituye la hipótesis que debatimos aquí.

\section{El ANONIMATO DE LA MADRE}

\section{Presupuesto normativo}

A fin de comprender en sus justos términos el problema, debe abordarse primero el status quaestionis jurídico-positivo que lo condiciona en mi país. Su exposición básica viene ofrecida de manera muy adecuada en la Sentencia del Tribunal Supremo español de 21 de septiembre de 1999. En ella se asume con acierto el pormenorizado informe del Fiscal, cuyos principales puntos selecciono.

A su tenor, "debemos precisar-dice- el marco normativo específico del Registro Civil amparador de la ocultación de los datos de filiación materna": 
a). "El párrafo segundo del [artículo 167 del Reglamento del Registro Civil, aprobado por Decreto de 14 de noviembre de 1958] precisa que «el parte o declaración de los profesionales y personal de establecimientos sanitarios que tengan obligación de guardar secreto no se referirá a la madre contra su voluntad», añadiendo la nota diecisiete del modelo oficial de 1958 [Orden Ministerial de 24 de diciembre], "en este supuesto, póngase: desconocida», redacción intacta en la actualidad ahora recogida en la nota 15 de la redacción de 1988 [Orden Ministerial de 26 de mayo]".

b). "El artículo 182 del Reglamento del Registro Civil permite a la madre no matrimonial desconocer el hecho de su maternidad si en el parte facultativo se hubieran puesto sus datos de identidad".

c). "Estos preceptos del Reglamento del Registro Civil parecen constituir el desarrollo del artículo 47.I y concordantes de la Ley de Registro Civil de 8 de junio de 1957, expresivo de que en la inscripción de nacimiento constará la filiación materna, siempre que en ella coincidan la declaración y el parte o comprobación reglamentaria. "Complementan el sentido de esta norma los preceptos sobre formalización del desconocimiento de la filiación por la madre (artículo 47.II y III de la Ley de Enjuiciamiento [rectius: del Registro] Civil)»".

d). "A su vez, el artículo $120.4^{\circ}$ del Código Civil en la redacción de la Ley núm. 11/1981, de 13 de mayo, previene que la filiación matrimonial quedará determinada legalmente, respecto de la madre, cuando se haga constar la filiación materna en la inscripción de nacimiento practicada dentro del plazo, de acuerdo con lo dispuesto en la Ley de Registro Civil".

e). "La «circular» de 2 de junio de 1981, sobre consecuencias registrales del nuevo régimen de filiación, en su apartado $I-C$ ) se refería sucintamente a esta coincidencia que necesariamente debería existir entre el dato de maternidad y el parte o comprobación reglamentaria".

Fundado en dicho panorama jurídico-positivo, se concluye que "nos encontramos, por ello, ante una regulación normativa registral anterior a la Constitución, que posibilita la ocultación de la identidad de la madre biológica, por su propia decisión, confirmada por los desarrollos reglamentarios posteriores a 1978, ya que la redacción del artículo 120 del Código Civil se configura en términos genéricos, y no incluye un expreso reconocimiento de tan negativa restricción".

2. Valoraciones enfrentadas:

la Resolución de la Dirección General española de los Registros y del

Notariado de 11 de abril de 1997 y su cambio de criterio

Las últimas expresiones citadas de la Sentencia de 21 de septiembre de 1999 resultan muy elocuentes. La percepción negativa del hecho no se disimula: "ya 
desde el inicio de la vigencia de dicha normativa registral, la doctrina expresó sus reservas a esta formulación del desconocimiento de la filiación, pues se entendía, frente al criterio de la Comisión de Reforma (el secreto profesional podría salvar la vida de niños recién nacidos, evitando así el aborto e infanticidio por parte de madres deseosas de evitar la divulgación de su maternidad extramatrimonial) que las graves razones de interés público en la determinación del vínculo de la filiación, cualquiera que fuere su clase, se oponían a esa ocultación; no posible, por otra parte, en cuanto a la entonces denominada "familia legítima», en la que tal conducta podría rozar el ámbito punitivo".

Estas consideraciones preliminares anuncian el sentido de la decisión, pero dudo que respondan imparcialmente a la realidad, incurriendo en algún grado de anacronismo. En el tiempo en que las aludidas disposiciones tabulares entraron en vigor, me temo que no existiera una opinión jurídica demasiado crítica con el anonimato de los padres respecto de la prole no matrimonial. En todo caso, "las graves razones de orden público" esgrimidas constituyen un fenómeno cierto, aunque posterior. Por último, el contraste de valores entre la determinación de la filiación y la vida de los recién nacidos o por nacer, arriesgada por el aborto y el infanticidio, no admite parangón igualitario y equidistante, como se intenta.

Tampoco cabe ignorar que la materia es profundamente polémica, pero existen firmes argumentos que avalan el mecanismo jurídico que permitía el anonimato de la madre para las circunstancias reseñadas. Un poderoso indicio constituye la Resolución de la Dirección General de los Registros y del Notariado de 11 de abril de 1997, cercana cronológicamente a la doctrina opuesta del Tribunal Supremo.

La idea mantenida por la Dirección General española puede calificarse de cautelosa y prudente, aun cuando manifiesta con toda certidumbre los intereses contrapuestos en cada óptica: "no es oportuno que este Centro Directivo se pronuncie ahora sobre una cuestión controvertida y en modo alguno indiscutible, como es la de decidir si esa facultad de la madre de ocultar su identidad vulnera derechos superiores del hijo a conocer sus orígenes y la prevalencia del principio mater semper certa est, o si, por el contrario, aquella facultad está en consonancia con el propio interés del menor, a veces el de su propia vida que se vería en peligro si su madre no tuviera la posibilidad de ocultar el parto. Basta recordar que el alumbramiento anónimo está admitido en otros países de la Unión Europea, como Francia, Italia y Luxemburgo".

En suma, la cuestión jurídica no es, ni en el fondo ni en la forma, pacífica. Incluso el informe del Ministerio Público en este caso discrepa de la tesis que más tarde defendió el Fiscal en la referida Sentencia de la Sala 1ª, por cuanto afirma las normas por entonces vigentes. Es decir, el argumento reduccionista del Tribunal Supremo no se vio precedido por otras instancias tan autorizadas en la esfera del estado civil de las personas como la Dirección General de los 
Registros y del Notariado; y tampoco logrará el respaldo posterior de prestigiosos organismos competentes por razón de la materia, del estilo del Tribunal Europeo de los Derechos Humanos, según consta después. A ello cabe añadir que también la evolución del Derecho comparado resulta en este punto discutible, porque la mayoría de los países levantan el anonimato de la madre, pero no sucede así en las culturas jurídicas más próximas a la española $(v$. gr. Francia e Italia) y el desarrollo en otros Estados ( $v$. gr. Alemania) señala variantes. Por último, los bienes sustantivos en liza no apuntan a soluciones simplistas: resulta elocuente un dilema entre conocimiento y certeza del origen de la prole y su propia existencia, que puede quedar comprometida.

Ahora bien, a partir de la tesis propiciada por la Sentencia del Tribunal Supremo de 21 de septiembre de 1999, el criterio del Centro directivo necesariamente ha virado, mas lo hace con innegable tono conformista. La Resolución $\left(2^{\mathrm{a}}\right)$ de 8 de noviembre de 2001 se plantea un asunto en el que la madre de 28 años confiesa obstáculos para poder asumir su responsabilidad, entre otras cosas por la situación carcelaria del padre, que provocan la tutela de la Comunidad Autónoma de Madrid. Recuerda que dicho fallo "del Tribunal Supremo se pronuncia de modo tajante sobre la inconstitucionalidad sobrevenida del artículo 167 del Reglamento del Registro Civil, que permitía a la madre ocultar la maternidad, no descubriendo su identidad en el parte médico de asistencia al parto. El Tribunal Supremo declara que este sistema se opone frontalmente a diversos preceptos constitucionales. No puede permitirse que el hijo biológico pierda por completo el nexo que le permitiría conocer su verdadera filiación, debido a un acto voluntario de la madre, expresivo de su no asunción de la maternidad y sus responsabilidades inherentes". En su virtud, "tal criterio ha sido compartido por este Ministerio que, al aprobar el nuevo cuestionario para la declaración de nacimiento (Orden Ministerial de 10 de noviembre de 1999), ha suprimido las referencias del antiguo cuestionario al citado artículo 167". "La maternidad queda, pues, determinada en nuestro Derecho por el hecho del parto, conforme al principio tradicional «mater semper certa est», cuya vigencia en todo el territorio español se produce desde que España se adhiriera en 1984 al Convenio internacional citado en los vistos"s.

A la vista queda que la vertiente axiológica es orillada por completo, y además el fundamento normativo utilizado resulta muy endeble, lo que contrasta con la envergadura de los intereses en juego. No sé bien qué se logra para la madre o el hijo con el reconocimiento de la filiación materna, cuando se impone a costa de todo y de todos, incluso a riesgo de la existencia del "beneficiario

${ }^{8}$ Se refiere al Convenio número 6 de la Comisión Internacional del estado civil de 12 de septiembre de 1962, sobre determinación de la filiación materna de los hijos no matrimoniales, al que se adhirió España: cfr. Boletín Oficial del Estado de 17 de abril de 1984. 
último" de la medida. En fin, la idea que se vindica tampoco supone un principio absoluto, como el propio Tribunal Constitucional reconoció salvaguardando el anonimato del donante de semen en la reproducción asistida heteróloga9.

\section{La inconstitucionalidad sobrevenida según la}

Sentencia del Tribunal Supremo español de 21 de septiembre de 1999

Establecido el escenario, conviene prestar atención al análisis de la Sentencia Tribunal Supremo $N^{\circ} 776 / 1999^{10}$, que declara la ineficacia sobrevenida del anonimato de la madre hasta entonces vigente. Su comentario abarca un doble aspecto: el del pleito que resuelve -a mi juicio, con fortuna-, y el de la doctrina general propuesta, creo que sin base rigurosa.

\section{a) La solución del litigio concreto:}

la nulidad de la renuncia preparto de la madre

El conflicto abordado fue si una madre que desconoció en su día la filiación, acogiéndose al régimen establecido por el Reglamento del Registro Civil, podía establecer el vínculo a posteriori. Ello implica desdecirse del consentimiento prestado antes de dar a luz, con recuperación de los derechos sobre su hijo, ahora bajo tutela del organismo público competente, que se opone y obstaculiza tales pretensiones.

Los hechos probados en el curso del proceso señalan "que previamente a su alumbramiento, el día 24 de septiembre del mismo año, la actora suscribió en documento [...] que manifestando encontrarse embarazada, en el octavo mes de gestación, y ponderando sus circunstancias concurrentes -familiares, sociales, emocionales y económicas- estima que no podrá hacerse cargo de su futuro

\footnotetext{
${ }^{9}$ Cfr. infra, III.

${ }^{10}$ Es el ponente Almagro Nosete, que también lo fue de otras sentencias que incluyen declaración de inconstitucionalidad sobrevenida de instituciones como la ejecución extrajudicial de las garantías reales (cfr. Sentencia de la Sala $1^{\text {a }}$ de 4 de mayo de 1998, contra las precedentes de 16 y 23 de octubre de 1995 de la Sala 3 ${ }^{a}$, todas del Tribunal Supremo español). El fenómeno resulta peligroso desde un punto de vista jurídico y, a veces, efímero. En dicho caso, la nueva Ley de Enjuiciamiento Civil -cfr. disposición final 9a a a artado 4º que modificó el artículo 129 de la Ley Hipotecaria- repuso el mecanismo. Considero que la fórmula española confiere al Tribunal Constitucional competencia prevalente sobre la materia. Acudir a otro recurso muchas veces desborda el ámbito de los concretos litigios planteados y hasta puede comprometer el equilibrio del sistema. Acerca de la inconstitucionalidad sobrevenida como concepto jurídico, véanse las interesantes opiniones de Rivero, Francisco, "De nuevo sobre el derecho a conocer el propio origen. El asunto Odièvre (Sentencia del Tribunal Europeo de Derechos Humanos de 13 de febrero de 2003)", Actualidad Civil No 24, 2003, p. 626; y RAmOs ChapARro, Enrique, "La inconstitucionalidad sobrevenida del desconocimiento materno", en Estudios Jurídicos en Homenaje al Profesor Luis Díez-Picazo, Civitas, Madrid, 2003, pp. 4901 y ss. Sobre la cuestión tampoco faltan recientes comentarios positivos en QueSADA GONZÁLEZ, "Algunas reflexiones sobre la maternidad a principios del siglo XXI", en Estudios Jurídicos en Homenaje al Profesor Luis Díez-Picazo, Civitas, Madrid, 2003, pp. 485 y ss.
} 
hijo, y ante ello, hace renuncia anticipada del mismo, una vez que nazca, en favor de la entidad pública, a los efectos de su guarda inmediata al parto, acogimiento familiar y adopción, en el marco establecido en la Ley núm. 21/1987, de 11 de noviembre, prestando su consentimiento expreso para la efectividad de todos estos actos, manifestando asimismo haber sido informada de sus derechos y de las consecuencias de su renuncia; y anticipando su asentimiento a la adopción, que adquiriría plena validez «transcurridos treinta días desde la fecha de nacimiento del menor». En la base de tal renuncia se consignaba su voluntad de mantener oculta su identidad, tanto a los efectos registrales civiles (artículo 167 del Reglamento del Registro Civil), como en el procedimiento de acogimiento y adopción, en sus fases administrativa y judicial, que debería tramitarse respecto del nacido, "como si de un menor desamparado y de padres desconocidos se tratase»". En su virtud, "la Administración autonómica asumió la tutela automática de la niña nada más nacer, según lo previsto en el artículo 172 del Código Civil".

Planteado el litigio en dichos términos, el Juzgado de primera instancia dictó Sentencia con fecha 6 de abril de 1994 "estimando en su integridad la demanda formulada [...] en nombre y representación de doña María V. M. contra la Junta de Andalucía, Consejería de Asuntos Sociales en Jaén, debo condenar y condeno a dicha demandada a que haga entrega a la actora de la hija que dio a luz en el Hospital "San Agustín de Linares», el día 4 de noviembre de 1991". Interpuesto el correspondiente recurso por el Ministerio Fiscal y el organismo condenado, la Audiencia Provincial de Jaén lo acogió con fecha 9 de septiembre de 1994 y falla "desestimando la demanda interpuesta por doña María V. M. contra la Junta de Andalucía Consejería de Asuntos Sociales sobre reclamación de filiación y entrega de un menor y con intervención del Ministerio Fiscal, debemos absolver y absolvemos a los referidos demandados de los pedimentos de la demanda".

Con tales premisas, se acudió a la casación. El Tribunal Supremo comienza reprochando a los órganos públicos intervinientes, incluido el Ministerio Fiscal, su actitud entorpecedora contra "el derecho de la menor a conocer al menos a su progenitora que establece, como principio, la Convención sobre los derechos del niño, de 1989, ratificada por España en 1990 (artículo 70)" y "el artículo 118 de la vigente Constitución Española, que considera obligado que se preste la colaboración requerida por los Jueces y Tribunales en el curso del proceso".

Así como el segundo de los aspectos merece la consideración objetiva que le presta el Tribunal, no me satisface la manera de asumir la primera de las garantías. Es falso que la Convención citada sobre los derechos del niño ${ }^{11}$ admita

${ }^{11}$ Hecha en Nueva York el 20 de noviembre de 1989 y publicada en el Boletín Oficial del Estado del 31 de diciembre de 1990 (en adelante, CDN). 
incondicionalmente y en abstracto que la prole conozca su origen biológico. Los términos legales expresan que "el niño será inscrito inmediatamente después de su nacimiento y tendrá derecho desde que nace a un nombre, a adquirir una nacionalidad y, en la medida de lo posible, a conocer a sus padres y a ser cuidado por ellos" (art. 7 CDN). En primer término, los derechos reconocidos no son lo absolutos que se pretende, habida cuenta que la inscripción en el Registro es un deseo más que una realidad, como también el amparo por una soberanía política. Sin embargo, ambas facetas están razonablemente atendidas en el Derecho español, que remedia su apatridia (cfr. art. 9.10 CC) y cuenta con un sistema de Registro Civil consolidado. Mas la fórmula sobre la deseable noticia del origen biológico queda muy supeditada en su reconocimiento a "la medida de lo posible". Una percepción maximalista del inciso conduciría sin remedio a su quiebra por el anonimato del donante del esperma en la fecundación in vitro, cosa que rechazó incluso el Tribunal Constitucional apenas tres meses antes (Sentencia de 17 de junio de 1999). A la postre, creo que con esta expresión posibilista el texto se refiere más bien al "interés superior del niño" (cfr. art. $3 \mathrm{CDN}$ ) que guía todas las actuaciones reflejadas en dicho Convenio, hasta el punto de permitir alternativas al cuidado de los progenitores si las circunstancias aconsejan otro proceder (cfr. art. 9 CDN). Luego las alegaciones vertidas en la Sentencia sobre dicho extremo resultan insatisfactorias, cuando no distorsionantes ${ }^{12}$.

Entrados en materia del asunto concreto que se ventila, la Sentencia resuelve, con razón, sobre la base de negar validez a los actos de la madre previos al alumbramiento: "ni la alegada renuncia al cumplimiento de sus deberes por la madre es válida, ni son de recibo posibles interpretaciones anticonstitucionales de las disposiciones reglamentarias sobre el Registro Civil". En efecto, "la renuncia anticipada -con un mes y medio de antelación- a unos derechosdeberes expectantes, pugna expresamente con lo dispuesto en el artículo $177.2^{\circ}$ del Código Civil, respecto de los consentimientos exigibles para la eficacia de la adopción, que claramente determina que el "consentimiento de la madre no podrá prestarse hasta que hayan transcurrido treinta días desde el parto»". "Como remarca el Fiscal dictaminante en el presente recurso", "el sentido de

\footnotetext{
${ }^{12}$ También critica esta cita Rivero, "De nuevo", cit. nota n. 10, p. 626. El autor desarrolla el panorama de los Convenios internacionales sobre la materia (cfr. Rivero, "De nuevo", cit. nota n. 10, pp. 605 y ss.). Su conclusión abunda en la línea de la Sentencia reproducida, que yo discuto. En este sentido, cita diversos instrumentos internacionales, cuya interpretación ambiciosa no me convence. Así, el Convenio para la protección de los derechos humanos y de las libertades públicas creo que arroja su verdadera eficacia en el affaire Odièvre que luego comentaré. Acerca del Convenio de Bruselas, № 6 de la Comisión Internacional de estado civil (1962), su contenido y expresiones no son fáciles de interpretar y, desde luego, tampoco causa en otros Estados adherentes el efecto que se desea para el español. En suma, no constituyen datos legales pacíficos y cuando existe ocasión de aplicarlos ad casum los jueces se apartan de cuanto propugnan algunos estudios teóricos.
} 
este precepto es meridiano. No existe viabilidad alguna de que el asentimiento a la adopción pueda ser prestado con antelación al parto, y ni siquiera en el período de treinta días computados desde el parto, ya que necesariamente debe manifestarse una vez transcurrido ese tiempo, es decir, el día treinta y uno; y nunca con anterioridad al momento del parto". "Las razones de esta cautela legal, se explican por la necesidad de garantizar la concurrencia plena de las facultades esenciales de libertad y conciencia en la madre biológica, para calibrar y ponderar detenida y serenamente la abdicación del ejercicio de su maternidad con la cesión en adopción del niño. Y si en el Texto Legal se habla del período posparto de treinta días, para que la recuperación de la madre sea plena física y psíquicamente, debe reconocerse que la situación personal, familiar, social y económica de la actora, cuando suscribió anticipadamente el documento de cesión, no era la más idónea para la ponderación de su asentimiento, que si pudo servir inicialmente para el acceso de la niña al acogimiento familiar, resultaba insuficiente y contrario a la ley en cuanto a la adopción, dada la configuración y trascendencia legal de la institución. El efecto de la contravención a una norma imperativa no es otro que la nulidad de pleno derecho (artículo $6.3 \mathrm{del}$ Código Civil). La entidad del vicio es de tal naturaleza que se extiende a todo el contenido del documento, concebido en atención a la obtención expedida (y, desde luego, «contra legem») de la autorización para adoptar, máxime cuando la identidad de razón para estimar inválido el consentimiento anticipado subsiste, conforme al artículo 173 respecto del acogimiento".

En cuanto al criterio sustentador del juicio ad casum, no existe atisbo de sombra sobre su conveniencia y responde del todo a los intereses debatidos en el litigio. Sin embargo, por inercia de la decisión -y, según creo, en un exceso injustificable, si rompe los intangibles límites del petitum-, el Tribunal Supremo se decide a establecer una doctrina novedosa sobre la constitucionalidad de la declaración de desconocimiento de la madre in genere.

b) La pérdida de vigencia general del mecanismo por contravenir la Constitución

La demanda en cuestión introdujo el debate del anonimato materno, pero desde la exclusiva faceta del arrepentimiento de quien en su día renunció a su protagonismo jurídico. Sin duda esta retractación debe ser atendida, mientras el beneficio del menor auspicie, o al menos tolere, un cambio de criterio. Sin embargo, ha de advertirse que más común es la experiencia contraria: la madre desconoce y no desea rectificar, incluso contra el posterior deseo del nacido. Es decir, la coyuntura impeditiva se mantiene.

Ahora bien, el Tribunal Supremo analiza no sólo el conflicto que se somete a su jurisdicción, sino la entera problemática que rodea el anonimato materno. 
En este sentido, tomar el todo por la parte, declarando contrario a la Constitución el mecanismo en su conjunto a partir del específico planteamiento que se produce, resulta, según creo, una imprudencia lamentable. Además, elimina precipitadamente fórmulas jurídicas que alivian a la madre cargas y angustias difíciles de apreciar en teoría. En su virtud, el riesgo de acudir a otras soluciones más traumáticas, sobre todo para la criatura, se reproducen de manera injusta y desmedida.

Según el criterio sustentado por la meritada Sentencia, "en la actualidad, y tras la vigencia de la Constitución de 1978 entendemos que tal limitación, elusiva de la constancia clínica de la identidad de la madre, ha quedado derogada por su manifiesta oposición a lo en ella establecido, y no debe ser aplicada por los Jueces y Tribunales (artículo 6 de la Ley Orgánica del Poder Judicial) siendo nulos, por ende, los actos producidos bajo su cobertura. En concreto, el sistema diseñado en los artículos 167, 182 y concordantes del Reglamento del Registro Civil, y sus disposiciones de desarrollo pugnan con el principio de libre investigación de la paternidad (artículo 39.2 de la Constitución española), y con el de igualdad (artículo 14), además de erosionar gravemente el artículo 10 de la Constitución española, al afectar a la misma dignidad de madre e hijo, a sus derechos inviolables inherentes a ella, y al libre desarrollo de su personalidad y al mismo artículo 24.1 en cuanto resulta proscriptivo de la indefensión. La coincidencia entre filiación legal y paternidad y maternidad biológica deben ser totales. Esta es la base desde la que decae la regulación reglamentaria permisiva de tal ocultación. Y desde ella deben ser contrastados sus elementos restrictivos. En líneas generales la regulación reglamentaria del Registro Civil supone una contradicción con el principio constitucional de igualdad e investigación libre de la paternidad, al situar a la madre biológica en situación relevante frente al padre, e incluso frente al mismo hijo, ya que al padre se le puede imponer coactivamente la paternidad, en tanto que la madre, que puede determinar libremente si va a continuar la gestación o cortar por completo sus relaciones con la persona nacida, tiene el camino despejado para eludir sus obligaciones".

Este inicial argumento me parece harto discutible. La mera invocación de normas constitucionales utilis ad omnia no justifica el sentido de su parecer. Resulta cada día mayor la perniciosa tendencia de acudir a preceptos evanescentes para sustentar pautas preestablecidas ${ }^{13}$, mientras las disposiciones de

\footnotetext{
${ }^{13}$ Rivero suma otros varios ejemplos -como los artículos 10.1, 14 y 39.2 de la Constitución (cfr. RIVERO, "De nuevo", cit. nota n. 10, p. 631)-, que me permito discutir. Particularmente me sorprende que aduzca el artículo 15 para defender que la integridad moral de la persona se vea mermada por la ignorancia sobre su origen biológico. La sutileza del discurso contrasta con la simple omisión de los primeros incisos de dicha norma, que salvaguarda el derecho de todos a la vida, cuya puesta en riesgo combatía el mecanismo que ahora se impugna de manera tan expeditiva. En su discurso, el autor termina por asumir "indirectamente reconocido el derecho de toda persona a conocer el propio
} 
cariz más jurídico quedan desprovistas de relieve técnico. El libre desarrollo de la personalidad de ninguna manera impide que la madre reconozca los obstáculos subjetivamente insalvables para poder asumir su destino. Que ajenos prediquen la verdadera dignidad de quien renuncia, por obra de circunstancias no deseadas, a su rol jurídico, linda con el autoritarismo. Exceso que deviene mayúsculo cuando se refugia en el artículo 24 de la Constitución. Pretender que causa indefensión el único mecanismo permitido a la madre para precaverse de un acoso social, económico e incluso familiar roza el despropósito. Por último, el artículo 10, que recoge la igualdad ante la ley, no resulta esgrimible sin otras consideraciones. Cómo desconocer que con respecto a la filiación el papel del padre y de la madre son distintos. En palabras del ilustre civilista que presidía las Cortes en el discurso de presentación del texto constitucional, "la igualdad en el Derecho no es como la igualdad de los objetos materiales, (que) consiste en su identificación, en su semejanza. La igualdad y la libertad en el Derecho significa trato igual para todos, pero dentro de la libertad y dentro de lo que la libertad significa de individualidad y sociabilidad"14. Otra perspectiva es la del uniformismo. La madre recibe lo mejor y soporta lo peor de la filiación. Lo primero debe ser apoyado y lo segundo remitido. El padre corre riesgo, en todo caso, de ver determinada su relación jurídica y asumir con ella las responsabilidades a que da lugar, pero la madre sobrelleva presiones de múltiples tipos, por desgracia no superadas en nuestro entorno, cuando la gestación no se circunscribe a un estado familiar estable. Las alternativas que se le ofrecen son de una crudeza extraordinaria, entre otras poner en trance la vida de la criatura que porta en su seno. Este peligro ha de conjurarse con prudentes dispensas de los elementos jurídicos de la compulsión, que la reduzcan a términos aceptables para los afectados.

Mas, al parecer, el alegado principio de igualdad se hace compatible con un tratamiento en España de doble rasero asombroso. El Tribunal Supremo recha-

origen, aun no explicitado en la Constitución ni en ley ordinaria" (RIvero, "De nuevo", cit. nota n. 10, p. 632). La idea es más expresiva del deseo que de realidades jurídicas palpables. Buena prueba consta en el salto lógico en que, a mi juicio, incurre cuando pasa de un presunto derecho indirectamente reconocido, pese a no tener vestigio alguno en el ordenamiento positivo, a que, de acuerdo con "los jueces disidentes de la mayoría en el caso Odièvre", defienda "la integración de ese "derecho a la identidad personal» en el respeto a su vida privada y familiar [...] como núcleo duro o fundamental de ésta determina que se halle especialmente protegido por la Convención de Derechos Humanos (art. 8)" (cfr., igualmente, Rubio Torrano, Enrique, "El secreto de la maternidad", Aranzadi Civil № 9, 2003, p. 13). Veremos más tarde que la decisión en dicho caso del Tribunal Europeo de Derechos Humanos (Sentencia de 13 de febrero de 2003: cfr. infra, II.4.b.3') se opone directamente a su tesis, por lo que pretenderla "integrada en nuestro ordenamiento, con las consecuencias pertinentes" (RIVERO, "De nuevo", cit. nota n. 10, pp. 631 y 632) es ilusorio.

${ }^{14}$ Hernández Gil, Antonio, en "Constitución Española. Trabajos Parlamentarios", IV, Cortes Generales (editor), Madrid, 1980. 
za el mecanismo del anonimato "al situar a la madre biológica en situación relevante frente al padre, e incluso frente al mismo hijo, ya que al padre se le puede imponer coactivamente la paternidad, en tanto que la madre, que puede determinar libremente si va a continuar la gestación o cortar por completo sus relaciones con la persona nacida, tiene el camino despejado para eludir sus obligaciones". Ahora bien, ello no es óbice para que apenas tres meses antes el Tribunal Constitucional exonerase a quien dona esperma de los requerimientos ahora tan absolutos para la mujer en la determinación de la filiación. Permanece libre de su obligatoriedad y hasta de su investigación. La Sentencia de 17 de junio de 1999, cuyo conocimiento público era evidente a raíz de la polvareda mediática que produjo, declara que "la Constitución ordena al legislador que "posibilite» la investigación de la paternidad, lo que no significa la existencia de un derecho incondicionado de los ciudadanos que tenga por objeto la averiguación, en todo caso y al margen de la concurrencia de causas justificativas que lo desaconsejen, de la identidad de su progenitor". Ya se ve que la igualdad va por sexos, pero siempre favorece a los mismos.

A propósito de la investigación de paternidad, la Sentencia del Tribunal Supremo tantas veces citada menciona también el artículo 39 de la Constitución entre los infringidos por el anonimato de la madre. Argumento más técnico que los anteriores, pero sin mejor destino. El artículo 39 de la Constitución española inaugura "los principios rectores de la política social y económica" (Capítulo III, de su Título I: "De los derechos y deberes fundamentales"); es decir, su reconocimiento, respeto y protección "informarán la legislación positiva, la práctica judicial y la actuación de los poderes públicos", aunque "sólo podrán ser alegados ante la Jurisdicción ordinaria de acuerdo con lo que dispongan las leyes que los desarrollen" (art. 53.3 CE). Luego el óbice para que los ciudadanos puedan emprender las oportunas acciones no se comparte por el Tribunal, quien de oficio aborda la cuestión a falta de una ley de concreto desarrollo que lo ampare. Sorprendente forma de proceder. Ello explica la cita de otros preceptos constitucionales, cogidos de refilón, para superar el obstáculo normativo que se le plantea.

Esto dicho, tampoco puedo compartir el criterio impuesto de manera casi absoluta de que "la coincidencia entre filiación legal y paternidad y maternidad biológica deben ser totales". El aserto es simplemente falso y en autoría de la más alta instancia del poder judicial español (cfr. art. 123.1 CE) produce repulsa por inexcusable. Por si cupiera duda razonable, prestemos atención al Tribunal Constitucional en afirmaciones realizadas tres meses antes: "es por ello perfectamente lícito, desde el punto de vista constitucional, la disociación entre progenitor biológico y padre legal"15.

${ }^{15}$ Obsérvese que, según las citas textuales, la pauta rigurosa corresponde a la maternidad, mientras la complaciente obra en el padre. No es lo que se dice un lapsus linguae. 
En efecto, el principio de verdad biológica tiene señaladas excepciones en el Derecho español; y no me refiero sólo a la controversia protagonizada por leyes especiales. Un buen caso se ofrece por los artículos 125 y 124 del Código Civil. El primero impide que se conozca el origen biológico incestuoso sin autorización judicial. El segundo inaugura otras alternativas para la madre con vistas a establecer nuevos vínculos familiares para el hijo. Ambos preceptos se fundan en el axioma de favor filii. Hoy en día, nadie obsta que sean inconstitucionales por esta causa. En fin, me gustaría saber dónde queda la doctrina del Tribunal Constitucional que después analizaré acerca del anonimato del padre para las fecundaciones asistidas o artificiales. El resultado último vuelve a discriminar a la madre, quien asume su papel completamente al margen de las dificultosas situaciones personales por las que atraviese, aunque no siempre los padres biológicos sigan el mismo camino.

Otra perspectiva complementaria se aborda en la Sentencia. Junto a la obligación de los progenitores a la hora de fijar el vínculo con el hijo, se plantea el derecho que a éste asiste de conocer su origen biológico, incluso en términos de identidad propia: "el hijo biológico, además, pierde por completo el nexo que le permitiría, en su momento, conocer su verdadera filiación, debido a un acto voluntario de la madre, expresivo de su no asunción de la maternidad y sus responsabilidades inherentes". La frialdad con que se rechazan los impulsos maternos produce verdadero trastorno. Sugerir que una madre que ha culminado un embarazo contra cualquier especie de obstáculos personales desea casi por capricho desprenderse del vínculo tan dificultosamente producido es algo que repele a la razón y a la conciencia. Por si fuera poco, reproduce una grave falta de sintonía entre las distintas instancias judiciales cuando juzgan sobre la constitucionalidad. La más especializada por razón de la materia entiende por el contrario que cuando se trata del padre, "no puede afirmarse, por ello, que la regulación legal, al preservar la identidad de los donantes, ocasione consecuencias perjudiciales para los hijos con alcance bastante para afirmar que se produce una desprotección de éstos". A ello se añaden nuevos datos jurisprudenciales. Resulta de gran interés la doctrina sobre les neés sous $X$ formulada por el Tribunal Europeo de Derechos Humanos, en el arrêt de grande Chambre dans I'affaire Odièvre c. France. Juzga respetuosa con el Convenio la legislación francesa que aún garantiza el remedio último del anonimato para la madre, pese a su reforma en el año 2002, según veremos. No coincide que otras experiencias abonen el campo abierto en España.

Una vez esgrimido el argumento de la igualdad en su perspectiva externa, también aduce la Sentencia del Tribunal Supremo el necesario equilibrio interno entre los tipos de filiación enfrentadas. El anonimato materno concebido en sus anteriores términos supondría reconocer diferencias insalvables para los modos de la determinación de la prole matrimonial y extramatrimonial. "Por último, el 
sistema encierra graves discordancias, no sólo con relación a los mismos padre e hijo biológicos, sino también frente a la unión matrimonial, en la que la madre no puede renunciar a su maternidad ni negar al hijo el hecho de su filiación, ni el padre deshacer por sí solo la presunción de su paternidad, lo que no resulta constitucionalmente congruente, máxime cuando las investigaciones científicas tienden, en la actualidad, a poner de relieve las interrelaciones biológicas que se desprenden de los antecedentes genéticos y su influencia, de manera, que cabe hablar del derecho de las personas a conocer su herencia genética. El sistema recientemente acogido por la Instrucción de 15 de febrero de 1999 sobre constancia registral de la adopción, que posibilita la cancelación de la inscripción principal de nacimiento, abriéndose una nueva, con un régimen de publicidad limitada de la inicial, trasladable al ámbito en que nos encontramos, sí sería admisible y compatible con el respeto a los principios constitucionales que hoy quedan en entredicho".

Tales afirmaciones desde la pura óptica jurídica son francamente incomprensibles ${ }^{16}$, máxime dictadas por el Tribunal Supremo español, que practica en el asunto de la filiación un seguidismo respecto de ciertas normas jurídicas que arroja resultados contraproducentes. Como afirma la Sentencia de 28 de noviembre de 2002, "la reglamentación del Código Civil sobre legitimación para el ejercicio de las acciones de impugnación de la filiación aparece inspirada por el principio de que la investigación de la verdad biológica debe resultar atemperado por la necesidad de preservar la paz familiar y la intimidad de las relaciones matrimoniales, de tal forma que se establece un sistema en el que la legitimación activa para impugnar una filiación matrimonial aparece mucho más restringida"1 ${ }^{\prime 7}$. En su virtud, el artículo 136 del Código Civil contempla que "el marido podrá ejercitar la acción de impugnación de la paternidad en el plazo de un año contado desde la inscripción de la filiación en el Registro Civil. Sin embargo, el plazo no correrá mientras el marido ignore el nacimiento". Su aplicación estricta no repara en desconocer las pruebas biológicas contradic-

\footnotetext{
${ }^{16}$ Tampoco Rivero se muestra conforme: cfr. Rivero, "De nuevo", cit. nota n. 10, p. 627.

${ }^{17}$ La Sentencia de 3 de diciembre de 2002 ofrece una resistencia denodada en este aspecto: "la paz familiar, tan frecuentemente invocada en pro de mantener, pasado un cierto tiempo, la situación paterno-filial creada con la presunción legal de paternidad, abonan en el supuesto contemplado la impugnación, ya que la tan deseada pacificación en modo alguno puede ser consentida desde el formalismo, sustentado sobre una actuación fraudulenta y como tal -artículo 6.4 del Código Civilcontraria, desde su origen a Derecho, cuyas normas se resisten a ser aplicadas produciendo un efecto de indefensión constitucionalmente vedado, y con olvido de la investigación de paternidad también constitucionalmente admitida sin limitaciones en sí ni en unas consecuencias, que imperativos de culto a la verdad y equidad y al espíritu y finalidad que han de inspirar la aplicación de las normas -artículos 3.1 y 2 del Código Civil-impiden desconocer, desde aquel artículo 39.2 de la Constitución española, ignorado si es que se concluyese en la prevalencia de la presunción "pater is est», pese a que no se corresponde con la realidad".
} 
torias con las efectivas presunciones de paternidad (hasta en el alumbramiento por una esposa de cuatro hijos, todos ajenos, pero reputados sin retorno del marido $)^{18}$. Sin embargo, ya son varias las ocasiones en que se aparta de la línea severa, como en las Sentencias de 30 de enero de 1993'19, 23 de marzo de 2001, 3 de diciembre de 2002 y 15 de septiembre de 2003. Esta tendencia se ha visto avalada definitivamente -y de forma laudable desde la perspectiva de la seguridad jurídica, si bien no resulte muy respetuosa con la literalidad de la ley- en las Sentencias del Pleno del Tribunal Constitucional 138 y 156/2005 de 26 de mayo y 9 junio respectivamente ${ }^{20}$, pues "estimando una cuestión de tal clase, declaró inconstitucional el párrafo primero del artículo 136 del Código Civi. en la redacción dada por la Ley 11/1981, de 13 de mayd en cuanto comporta que el plazo para el ejercicio de la acción de impugnación de la paternidad matrimonial empiece a correr aunque el marido ignore no ser el progenitor biológico de quien ha sido inscrito como hijo suyo en el Registro Civil", doctrina contemplada ya en la jurisprudencia ordinaria por la Sentencia del Tribunal Supremo núm. 891/2005 de 23 noviembre ${ }^{21}$.

En todo caso, es indudable que las filiaciones derivadas del matrimonio y las no matrimoniales gozan de disciplinas jurídicas distintas en su base, por cuanto la forma primaria de su determinación en la primera hipótesis son las presunciones $^{22}$. Por eso se habla del marido como idéntico a padre del hijo de su

\footnotetext{
${ }^{18}$ Es el supuesto descrito en la Sentencia de 31 de diciembre de 1998, que no constituye una excepción, al margen de la peculiaridad del caso, al ser alegada su doctrina en las Sentencias de 14 de octubre de 1985; 22 de diciembre de 1993; 20 de junio de 1996; 10 de febrero de 1997; 21 de julio y 30 de septiembre de 2000; 31 de diciembre de 2001; 26 de junio de 2002; y 26 de junio de 2003.
}

${ }^{19}$ La Sentencia de 26 de junio de 2002 se permitía reducir su incidencia jurídica: "la Sentencia disconforme de 30 de enero de 1993 no constituye doctrina y no resulta prevalente, como dice la Sentencia de 31 de diciembre de 1998". Ahora bien, el Tribunal Supremo, en plena ceremonia de la confusión, se contradice in terminis varias veces: en 1998 la rectificación no vale, pero en 2001 se reaviva, para perder su vigor de nuevo en junio 2002, recuperarlo seis meses más tarde (diciembre de 2002), y contra el retroceso de la Sentencia de 26 de junio de 2003, consolidarse a raíz de la Sentencia de 15 de septiembre de 2003, de paupérrimo contenido. Alguien debía poner remedio semejante despropósito, lo que protagoniza el Tribunal Constitucional español en su novedosa jurisprudencia que analizo de inmediato.

${ }^{20}$ La solución no fue pacífica, pues el fallo cuenta con dos votos particulares suscritos por tres magistrados.

${ }^{21}$ A la vista de un panorama tan convulso, la Sentencia de 1 de diciembre de 1993 dirime si las diferencias entre la normativa de Cataluña y la civil común en orden a las personas legitimadas para impugnar la filiación fundan un episodio discriminatorio de la ley respecto a los individuos sometidos a uno u otro sistema (fenómeno que se reproduce, como en la Sentencia de 31 de diciembre de 1998), pero "el tratamiento desigual que se invoca en el recurso deriva de las particularidades del Derecho Especial de Cataluña, cuyas diferencias con el régimen común no constituyen desigualdad ante la ley, pues de no entenderse así carecería de sentido la propia existencia de los Derechos forales o especiales".

${ }_{22}$ Resulta en este punto elocuente la Sentencia de 14 de octubre de 1985, en la que se justifica por extenso el fenómeno: "la presunción de paternidad en la filiación matrimonial con arreglo al principio 
esposa. Es interesante observar que dicho esquema vence a la contraria verdad biológica $^{23}$. Luego la falta de paralelismo jurídico hace imposible un tratamiento uniforme para las filiaciones al margen del matrimonio de los progenitores.

A la postre, "la Sala, por tanto, estima, de conformidad con el Ministerio Fiscal, que el artículo 47.I de la Ley de Registro Civil de 8 de junio de 1957 (y sus concordantes) están derogados por inconstitucionalidad sobrevenida, en el particular, que permite interpretaciones reglamentarias que hagan depender de la voluntad de la madre, la circunstancia registral de la maternidad. En consecuencia se consideran inaplicables, por derogación de la cobertura legal, en el mismo sentido, los artículos 167 y 182 del Reglamento"24.

Según creo, las consideraciones vertidas a lo largo de la Sentencia y que ya he reproducido por extenso se aproximan al agravio. Vienen a significar que la defensa del derecho de los hijos a conocer su origen biológico es superior a su amenaza de aborto. Mientras el vínculo de filiación se alza en un presupuesto irrenunciable del orden público, la coyuntura de la madre, por angustiosa que sea, no logra equipararse a él, aunque la empuje a tomar medidas perjudiciales tanto para ella como para el hijo, que a buen seguro pudieran evitarse de otra forma. Sinceramente no puedo compartir dicha jerarquía de valores. Cuánto me gustaría que los jueces de la Sala $1^{\text {a }}$ del Tribunal Supremo español fuesen

«pater is est», de muy rancio abolengo, pues arranca de un conocido texto del Derecho Romano («pater vero is est quem nuptiae demostrant»: D. 2, 4, 5), sancionador del hecho de tal relación consanguínea cuando el nacimiento se ha producido «ex uxore», principio que pasó al Derecho Canónico medieval ("qui natus est de uxore alicujus, praesumitur filius iustus») y por fin a la Codificación, según es de ver en los artículos 101 del Proyecto de 1851 y 108 del Código Civil de 1889, ciertamente no obsta a la promoción de acciones negando la paternidad marital, tema en el que la reforma de 13 de mayo de 1981 ha significado un cambio profundo de la normativa precedente, que limitaba el supuesto a la evidencia de la imposibilidad física de acceso carnal en el período de la concepción (artículo 108, párrafo 2), pues si de un lado prescinde de reafirmar la presunción de paternidad «a marito» como lo hiciera el derogado artículo 109, cuyo primer inciso cuenta también con un ilustrativo antecedente en la legislación alfonsina («ensáñanse las mujeres a las vegadas tan fuertemente que, por despecho que han de los maridos, dicen que los fijos que tienen en los vientres, o, que son nacidos, que no son de ellos, más de otros», ley 9a , título 14, Partida tercera), de otro amplía los plazos de caducidad de la acción (artículos 136 y siguientes) y no constriñe las pruebas utilizables". Acaso ahora las cosas varíen y puede que las mujeres prefieran imputar al marido la prole ajena. Con todo, creo que dicho panorama merece un juicio muy benévolo a la Sala $1^{\text {a }}$ del Tribunal Supremo español.

${ }^{23}$ El Tribunal Supremo español, entiende que si "la reforma de 1981 tuvo como uno de sus presupuestos asentar la filiación sobre la verdad biológica" (Sentencias de 3 de diciembre de 2002, con cita expresa de la Sentencia de 30 de enero de 1993), ésta debe prevalecer sobre otras consideraciones. Ahora bien, tampoco cabe omitir que, junto con este principio cierto, se fijaron otros límites ex favor filii, que recortan su eficacia en múltiples ocasiones (v. gr., entre otros, arts. 123, 124 y 125 CC).

${ }^{24}$ Añade la propia Sentencia que "tampoco, como se insinuó, cabe buscar cobertura en una normativa periclitada si ésta no se interpreta «secundum constitutionis». Al respecto compartimos plenamente los criterios expuestos por el dictamen del Ministerio Fiscal, en el trámite prevenido por el artículo 1710.2 de la Ley de Enjuiciamiento Civil". Es Ilamativa la constante reiteración de sintonía con el informe del Ministerio Público. 
más permeables a las necesidades propias del otro sexo, en unas condiciones familiares, sociales, psicológicas y económicas que no parecen compartir, ni acaso representarse, por mucho que surquemos ya el Siglo XXI. La técnica jurídica se impone a la vida, de suerte que gracias a consideraciones genéricas sucumben instrumentos defensivos que merece la pena conservar, aunque sólo en ocasiones sean utilizados. Cabe preguntarse qué sería mejor para la nueva criatura: existir o conocer su origen biológico. En estos términos curiosamente se planteó el debate por el Tribunal Europeo de Derechos Humanos, con un resultado, a mi juicio, más satisfactorio.

4. El refrendo del parto anónimo de la madre según el Tribunal Europeo de Derechos Humanos

a) Prolegómeno: valor interno de las Sentencias del Tribunal de Estrasburgo

La relevancia jurídica que cabe conferir a las decisiones del Tribunal Europeo de Derechos Humanos ${ }^{25}$ ha sido perfectamente fijada en el ordenamiento español por la jurisprudencia ${ }^{26}$. Estimo que constituye un dato de interés para la disciplina que se aborda, por lo que su análisis, aunque introductorio, resulta ineludible.

En breve síntesis, hay que reconocer que, al margen de su respaldo teórico, perdura una corriente amplia de opinión sobre una presunta entidad práctica desmedida de su doctrina, sobre todo a raíz del caso Marckx (STEDH de 13 de junio de 1979). Sin embargo, constituye un elemento de autoridad o de prestigio, pues, en su propia cita, "la Sentencia del Tribunal es esencialmente declarativa y deja al Estado la decisión de los medios a utilizar en su ordenamiento jurídico interno para adaptarse a lo que le impone el artículo 53" del Convenio. El decisivo impulso que proporcionó la tesis del Tribunal allí expuesta en la reforma del Derecho de familia en Bélgica induce a la creencia, lejos de nuestra órbita jurídica continental, de su carácter ejecutivo inmediato, cuando no es así "según se infiere, no sólo, del artículo 50 del Convenio Europeo de Salvaguarda de Derechos Humanos y Libertades Fundamentales («El Convenio»), sino también de pacífica y consolidada jurisprudencia de dicho TEDH, como son las emblemáticas Resoluciones de 25 de abril de 1983 (Caso Pakelli) y 24 de febrero de 1984 (Caso Digeon), que establecen que el Convenio no atribuye competencia al Tribunal, ni para anular la sentencia, ni para ordenar la desautorización de

\footnotetext{
${ }^{25}$ En adelante TEDH, "conocido, asimismo, con el nombre de la localidad en donde ejerce su función: Estrasburgo" (Sentencia del Tribunal Supremo de 20 de noviembre de 1996).

${ }^{26}$ Existen varios casos en la Sala $2^{a}$ del Tribunal Supremo, más proclive por razón de la materia (cfr. Sentencia de 4 de abril de 1991), sin perjuicio de algún supuesto de la Sala ${ }^{a}{ }^{a}$, como la Sentencia de 20 de noviembre de 1996, relativo a propiedad intelectual.
} 
los temas objeto de la queja" (Sentencia del Tribunal Constitucional español de 16 de diciembre de 1991).

En efecto, prosigue la citada Sentencia de nuestro Tribunal Constitucional, "para corroborar lo anterior, se debe afirmar que el ordenamiento judicial español no prevé la ejecución de sentencias internacionales -no confundir con sentencias dictadas por Tribunales extranjeros, cuya ejecución puede llevarse a cabo por Tribunales españoles-. Pero es que, además, el TEDH no es un órgano judicial supranacional; pues el reconocimiento del Estado español de la jurisdicción de dicho Tribunal, no puede exceder a lo previsto en el artículo 46 del Convenio, que colateralmente prohíbe dar naturaleza de Tribunal nacional de última instancia definitiva al Tribunal de Estrasburgo. Sobre todo porque el artículo 117.3 de la Constitución española, establece que el ejercicio de la potestad jurisdiccional de todo tipo de procesos, juzgando y haciendo ejecutar lo juzgado, corresponde exclusivamente a los Juzgados y Tribunales españoles determinados por las leyes. Y, hoy por hoy, introducir el TEDH en la organización judicial española, sólo sería factible a través de una «lex data» de naturaleza orgánica, a tenor de lo dispuesto en el artículo 81.1 de la Constitución de España". En fin, "todo lo anterior lleva inexorablemente a la conclusión de la no posibilidad de producir efectos anulatorios las sentencias tanto del TEDH, como de las decisiones del comité de Ministros, en el ordenamiento jurídico español, pues para que ello fuera posible tendrían que utilizarse los siguientes caminos: a) Modificar la legalidad actual, como han hecho los Estados de Noruega, Luxemburgo, Malta y el cantón suizo de Appenzell, estableciendo un nuevo motivo de revisión de sentencias firmes, o b) La firma de un nuevo protocolo de Convenio, que estableciera un procedimiento para el cumplimiento de las resoluciones de TEDH o las decisiones del Comité de Ministros, por los Estados demandados". Es decir, "ha de darse la razón al Tribunal Supremo cuando afirma que la Sentencia pronunciada por el TEDH es una resolución meramente declarativa, sin efecto directo anulatorio interno, ni ejecutoriedad a cargo de los Tribunales españoles", pues "desde la perspectiva del Derecho Internacional y de su fuerza vinculante (art. 96 CE), el Convenio ni ha introducido en el orden jurídico interno una instancia superior supranacional en el sentido técnico del término, de revisión o control directo de las decisiones judiciales o administrativas internas, ni tampoco impone a los Estados miembros unas medidas procesales concretas de carácter anulatorio o rescisorio para asegurar la reparación de la violación del Convenio declaradas por el Tribunal (o, en su caso, por el Comité de Ministros de acuerdo al artículo 32 del Convenio). El Convenio no obliga a los Estados miembros a eliminar las consecuencias del acto contrario, a la obligación jurídica internacional asumida por el Estado, restableciendo en lo posible la situación anterior a ese acto, antes bien el artículo 50 permite sustituir por una satisfacción equitativa ese restablecimiento 
que pone en cuestión el carácter definitivo y ejecutorio de la decisión judicial interna, si bien tal satisfacción equitativa sustitutoria sólo entra en juego cuando el derecho interno no permite la reparación perfecta de las consecuencias de la resolución o Sentencia estatal".

Ahora bien, tampoco se niega la relevancia de sus fallos, descritos en la Sentencia de la Sala de lo Militar del Tribunal Supremo español de 27 de enero de 2000: "no podemos dejar de recordar el valor declarativo que la Sentencia de 28 de octubre de 1998, como las demás del TEDH, tiene en el Derecho interno español, y su fuerza de obligar, como emanada de un Tribunal jurisdiccional a cuyas decisiones nos hemos comprometido conformar, según el artículo 53 del Instrumento de ratificación del Convenio para la protección de los Derechos Humanos y Libertades Fundamentales, hecho en Roma el 4 de noviembre de 1950, y con fuerza de obligar para España, a partir del 4 de octubre de 1979; además, lo mismo cabe deducir de lo establecido en los artículos 10 y 96 de nuestra Constitución, respecto al valor interpretativo hecho por el referido TEDH del citado Convenio de Roma de 1950, y el valor como Derecho interno del referido Convenio".

En suma, "según la opinión absolutamente dominante, el Convenio no obliga a dar efecto interno a las Sentencias del Tribunal Europeo mediante la anulación de la autoridad de cosa juzgada y de la fuerza ejecutoria de la decisión judicial nacional que dicho Tribunal haya estimado contraria al Convenio. Tampoco el artículo 13 del Convenio confiere al justiciable un derecho para ampliar los motivos previstos en el derecho interno para la reapertura del procedimiento judicial que ha dado lugar a una Sentencia firme y ejecutoria". Con todo, ello "no significa que en el plano de nuestro sistema constitucional de protección de los derechos fundamentales los poderes públicos hayan de permanecer indiferentes ante esa declaración de violación del derecho reconocido en el Convenio". Es decir, "no implica la carencia de todo efecto interno de la declaración realizada por dicho Tribunal sobre la existencia de infracción de un derecho reconocido en el Convenio. Ha de tenerse en cuenta que el Convenio no sólo forma parte de nuestro Derecho interno, conforme al artículo 96.1 de la Constitución española, sino que además, y por lo que aquí interesa, las normas relativas a los derechos fundamentales y libertades públicas contenidas en la Constitución española, deben interpretarse de conformidad con los tratados y acuerdos internacionales sobre las mismas materias ratificados por España (art. 10.2 CE), entre los que ocupa un especial papel el Convenio para la Protección de los Derechos Humanos y de las Libertades Fundamentales. EI TEDH es el órgano cualificado que tiene por misión la interpretación del Convenio, y sus decisiones son además obligatorias y vinculantes para nuestro Estado, cuando sea Estado demandado. De ello se sigue que, declarada por Sentencia de dicho Tribunal una violación de un derecho reconocido por el Convenio Europeo que 
constituya asimismo la violación actual de un derecho fundamental consagrado en nuestra Constitución, corresponde enjuiciarla a este Tribunal, como Juez supremo de la Constitución y de los derechos fundamentales, respecto de los cuales nada de lo que a ello afecta puede serle ajeno" (Sentencia del Tribunal Constitucional español de 16 de diciembre de 1991).

Con tales premisas, y en la materia que aquí se trata, existe una Sentencia del $\mathrm{TEDH}$, cuya doctrina resulta del mayor interés al efecto de medir las verdaderas repercusiones que acerca de los derechos humanos reconocidos en el Convenio tiene una legislación que permita el desconocimiento materno. Su perspectiva sirve también para los derechos fundamentales recogidos en la Constitución española y, por cierto, contrasta profundamente con la tesis aventurada por nuestro Tribunal Supremo.

\section{b) El affaire Odièvre: los hechos}

El asunto de referencia se produce a partir de una demanda contra el Estado francés de fecha 1 de noviembre de 1998, en la que la promotora, Dña. Pascale Odièvre "alega que el secreto de su nacimiento y, como resultado de ello, la imposibilidad para ella de conocer sus orígenes, constituía una violación de los derechos garantizados por el artículo 8 del Convenio y una discriminación contraria al artículo 14 del Convenio".

La Sentencia realiza un estudio exhaustivo y elocuente de la problemática en sus distintas facetas, tanto fácticas como jurídicas. Nada mejor, pienso, que dejarse guiar por su contenido en el desarrollo de la materia que ahora emprendo.

El discurrir histórico de los acontecimientos debatidos puede sintetizarse a partir de los siguientes episodios:

$\left.1^{\circ}\right)$ La demandante nació el 23 de marzo de 1965 en París, resultando sietemesina. Su madre, Berthe, solicitó el anonimato del alumbramiento, para lo cual firmó un acta en los siguientes términos: "abandono a mi hija Berthe Pascale. Certifico haber sido informada de que, pasado el plazo de un mes, mi hija será definitivamente abandonada y de que la Administración se reserva la facultad de darla en adopción.- Rechazo las ayudas que me han sido propuestas.- Solicito el secreto de nacimiento".

$2^{\circ}$ ) Ya bajo la custodia de los servicios de asistencia social a la infancia, la demandante fue matriculada el 1 de julio de 1965 entre los pupilos del Estado del Departamento del Sena. Resulta posteriormente concedida su adopción-con arreglo a Resolución del Tribunal de Gran Instancia de París el 10 de enero de 1969- a los señores Odièvre, cuyo apellido actualmente porta.

$3^{\circ}$ ) Habiendo tenido constancia de sus orígenes a finales de 1990, la actora obtuvo noticias no identificativas sobre su familia biológica, que constan en 
el expediente administrativo, entre otras las siguientes: "Los padres conviven maritalmente desde hace siete años. De su unión han nacido dos hijos, el mayor de 21 meses y Pascale [...]. La pareja se encuentra hospedada desde hace dos años pero la patrona está amenazada de expulsión. El padre es de nacionalidad española, ejerce la profesión de pintor de edificios, su sueldo mensual es de alrededor de 1.200 francos. Está casado y tiene una hija legítima criada por la madre. Según dice la depositante, su amigo no quiere oír hablar de Pascale, declara que no puede asumir esta nueva carga. La señora Berthe parece sin voluntad, se somete sin pena al deseo de su amigo. Nunca ha visitado a su hija en la clínica, dice que no quería encariñarse. Sólo la ha visto hoy, y se separa de ella con absoluta indiferencia. La señora Berthe no trabaja, cría a su hijo y cuida del de su patrona"; "Señas de la madre: talla $1 \mathrm{~m}$. 63, delgada, rostro de rasgos regulares, tez clara, ojos castaños muy maquillados, cabello largo castaño-espeso -está sana- de un estilo ambiguo; medios intelectuales muy limitados.- Señas del padre: talla mediana, cabello rubio, ojos castaños, en buena salud, sobrio" ${ }^{27}$.

$4^{\circ}$ ) El 27 de enero de 1998 Dña. Pascale Odièvre presentó una demanda ante el Tribunal de Gran Instancia de París, con el fin de solicitar el "levantamiento del secreto de su nacimiento autorizando a que se le comunicaran todos los documentos de estado civil, actas civiles y partidas íntegras de nacimiento completos". A tal propósito, señalaba la información de que sus padres tuvieron un hijo en 1963 y posteriormente otros dos hijos después de 1965, aun cuando persistía la negativa oficial para facilitarle informaciones acerca del estado civil de sus parientes, debido a que dicha comunicación vulneraría el secreto de nacimiento. El 2 de febrero de 1998 el Tribunal comunicó al abogado de la demandante que, "tras un examen de su expediente por parte de la vicepresidenta de la primera Sala, parece que la demandante debe eventualmente recurrir al Tribunal administrativo para obligar, si puede, a la Administración a levantar el secreto, lo que sería en todo caso contrario a la Ley de 8 de enero de 1993".

$5^{\circ}$ ) Agotados los recursos que le permite su legislación nacional, con fecha de 1 de noviembre de 1998 se insta la demanda contra el Estado francés (núm. 42326/1998), que daría lugar a la Sentencia de la Gran Sala del Tribunal Europeo de Derechos Humanos de 13 de febrero de 2003 (núm. 2003/8).

\footnotetext{
${ }^{27}$ Destaco el hecho por su indudable paralelismo con lo prevenido en el artículo 5.5, párrafo 2, LTRHA: "los hijos nacidos tienen derecho por sí o por sus representantes legales a obtener información general de los donantes que no incluya su identidad". Véase una posible traducción práctica del asunto, expresada en términos casi costumbristas y no precisamente alentadores.
} 
c) El affaire Odièvre: legislación aplicable y perspectivas de futuro. Francia y Derecho comparado

Sobre los hechos fijados, la Sentencia se ocupa de los datos jurídico-positivos aplicables. En esta línea, reconoce que "la norma «Mater semper certa est» nunca fue aceptada por el Derecho francés. Existe en Francia una tradición antigua de abandono organizado de neonatos". En el capítulo de los precedentes, dicha práctica vino a ser mitigada en sus negativos efectos por la obra de San Vicente Paul (1638) que introdujo el uso del torno, con el propósito de combatir los infanticidios, los abortos o los desamparos. La Convención revolucionaria (1793) seguiría idéntico derrotero en el parto anónimo de la madre, pero garantizando asimismo su atención médica y económica. Por Ley de 27 de junio de 1904 se profundizó en el proceso, mediante la "oficina abierta" día y noche para el depósito de los recién nacidos sin revelar a la madre, a quien se le ofrece ayuda e indica las consecuencias de su conducta. Esta política de apoyo a la maternidad secreta quedó plasmada con el Gobierno de Vichy en el Decreto-ley de 2 de septiembre de 1941 sobre la Protección del Nacimiento, que defendía el alumbramiento anónimo y el auxilio a la mujer embarazada durante los meses anteriores y el mes siguiente al parto en cualquier establecimiento público.

El Sistema, tras algunas vacilaciones, fue reformado en 1986, para convertirse al artículo 47 del Código de la familia y de la asistencia social, y posteriormente al actual artículo L. 222.6 del Código de Acción Social y de la Familia: "los gastos de alojamiento y parto de las mujeres que hayan solicitado, al ingresar en un establecimiento público o privado concertado, que se preserve su identidad, correrán a cargo del servicio de asistencia social a la infancia del departamento sede del establecimiento". Este auxilio incluye "asistencia psicológica y social", para lo que "no se exigirá ningún documento de identidad ni se procederá a ninguna investigación". La Ley 1993/22, de 8 de enero, "modificadora del Código Civil relativo al estado civil, a la familia y a los derechos del niño e instituyendo un Juez para los asuntos de familia" consagraría el parto anónimo, concediendo una nueva dimensión al abandono materno. En su virtud, se impide la determinación de la filiación, gracias al artículo 341.1 del Código Civil, pues "en el alumbramiento la madre podrá solicitar que se preserve el secreto de su ingreso y de su identidad". A su vez, la ocultación sobre los orígenes cabe provenir de otra fuente, por cuanto los padres pueden entregar a su hijo menor de un año a los servicios de asistencia social a la infancia, solicitando el secreto de su identidad (antiguo artículo 62.4 del Código de la familia y de la asistencia social, convertido en el artículo L. 224.5, 4 del Código de Acción Social y de la Familia): el vínculo de filiación establecido en el acta de estado civil es anulado y da lugar a una partida de nacimiento ficticia llamada estado civil provisional. 
Este panorama legal en vigor no dejaría de ser discutido. A partir de la citada Ley de 1993, se sucedieron varias iniciativas oficiales acerca del alumbramiento anónimo. Aún antes, un informe del Consejo de Estado - «statuto y protección del menor» (1990)- promovía un derecho limitado de acceso de la progenie a la identidad de sus padres, por mediación de una estructura especialmente creada -«consejo para la búsqueda de los orígenes familiares»-, con la meta de conseguir la voluntad de los progenitores y llevar a cabo el apoyo psicológico de las partes. En 1995, el informe Mattéi propuso mantener el anonimato del nacimiento, pero contemplaba la obtención de referencias no identificativas. Otro informe de la comisión parlamentaria sobre derechos del niño (1998) propuso levantar el secreto "sobre la base de una solicitud común de la madre y del niño durante la minoría de edad de éste". Existen otros proyectos en este sentido (informes Théry, Dekeuwer-Défossez, etc.), que se plasmaron en la Ley 2002/1993, de 22 de enero, sobre "acceso a los orígenes de las personas adoptadas y pupilas del Estado".

A tenor de la norma, sin merma de la incólume base del parto anónimo, se autoriza la revocación del secreto de la identidad materna siempre que conste acuerdo explícito de la madre y del hijo $^{28}$. A este propósito, contempla un "Consejo nacional para el acceso a los orígenes personales" 29 y se incluye un primer párrafo al artículo L. 222.6 del Código de Acción Social y de la Familia en los siguientes términos: «toda mujer que solicite, con ocasión del parto, la preservación del secreto de su ingreso y de su identidad por un establecimiento sanitario, será informada de las consecuencias jurídicas de dicha solicitud y de la importancia para cualquier persona de conocer sus orígenes y su historia. Será por tanto invitada a facilitar, si lo acepta, informaciones sobre su salud y la del padre, los orígenes del niño y las circunstancias de su nacimiento así como, en pliego cerrado, su identidad. Será informada de la posibilidad de levantar en todo momento el secreto de su identidad y que, en caso contrario, su identidad no podrá ser comunicada sino en las condiciones previstas en el artículo L. 147.6. Será también informada de que podrá en todo momento facilitar su identidad en un pliego cerrado o completar las informaciones proporcionadas

\footnotetext{
${ }^{28}$ Suprime, por el contrario, la quiebra del secreto por la simple voluntad de los padres, tal y como se desprende del artículo L. 224.5 del Código de la Acción Social y de la Familia.

29 "Se compone de un magistrado del orden judicial, de un miembro del Tribunal administrativo, de representantes de los ministros en cuestión, de un representante de los consejos generales, de tres representantes de asociaciones de defensa de los derechos de la mujer, de un representante de asociaciones de familias adoptivas, de un representante de asociaciones de pupilos del Estado, de un representante de asociaciones de defensa del derecho al conocimiento de sus orígenes, y de dos personalidades cuya experiencia y competencia profesional médica, paramédica o social califiquen particularmente para el ejercicio de funciones en su seno". La Ley pormenoriza el modo de proceder en todos sus extremos.
} 
en el momento del nacimiento. Los nombres puestos al niño y, llegado el caso, mención del hecho de que fueron puestos por la madre, así como el sexo del niño y la fecha, el lugar y hora del nacimiento vendrán anotados en el exterior de dicho pliego. Las personas citadas en el artículo L. 223.7 cumplirán, advertidas de ello, con estas formalidades bajo la responsabilidad del director del establecimiento sanitario. A falta de ello, serán llevadas a cabo bajo la responsabilidad de dicho director». Como se observa, constituye una medida en fomento de la noticia de los orígenes biológicos, pero a resultas de la decisión de la madre, quien es informada e incluso recibe un cierto apoyo en pro de su actitud colaboradora. Igualmente, se subraya la libre revisión de su voluntad opuesta en un comienzo a darse a conocer.

Realizada la oportuna síntesis de la legislación francesa, cuya legitimidad a la vista del Convenio Europeo de Derechos Humanos se debate, también aparece un amplio repertorio comparatístico. Se analiza en sus directrices maestras y recoge lo concerniente al ordenamiento continental. Esta técnica no sólo ilustra el problema, sino que ofrece perspectivas de interés acerca de su desarrollo abstracto e implantación práctica. En este sentido, se concluye que "la maternidad anónima es poco conocida en las legislaciones internas europeas ya que únicamente Italia y Luxemburgo no imponen legalmente a los padres biológicos el registro del recién nacido o la declaración de su identidad durante el registro. Por el contrario, la indicación del nombre de la madre, que se vincula automáticamente al del hijo, así como el del padre, es obligatoria en numerosos países: Noruega, Holanda, Bélgica, Alemania [...], Dinamarca, Reino Unido, Portugal, Eslovenia o Suiza".

En realidad, observadas detenidamente las cosas, el esquema que se acaba de reproducir constituye un buen indicio de la exposición del Derecho extranjero en la materia. Sin embargo, en la mejor línea de análisis jurídico-comparado y valorativo útil al estudio presente, tampoco cabe omitir que los países más relevantes de nuestro entorno, así, Francia e Italia acogen el sistema de desconocimiento de la madre ${ }^{30}$. Considero que tiene un valor mucho más acusado este panorama, frente a una simple acumulación de legislaciones contrarias, pero sin referencias comparables con la española, ya sea desde la perspectiva histórica, jurídica, cultural... e incluso geográfica. En todo caso, el TEDH, si bien por mayoría, como acostumbra en sus decisiones, no rechaza este régimen de parto anónimo a la vista de la Convención Europea de Derechos Humanos. A ello se suma que la controvertida legislación francesa proviene de una reforma

\footnotetext{
${ }^{30}$ Rivero discrepa, citando en contra "la mayor parte de los [sistemas] de nuestra área cultural y jurídica" (RIVERO, "De nuevo", cit. nota n. 10, p. 632), pero sin decir cuáles, salvo la exposición informativa y sin calificar que realiza (cfr. Rivero, "De nuevo", cit. nota n. 10, p. 601); eso sí, con una clara mayoría numérica desfavorable al anonimato materno.
} 
del año 2002. Luego no puede afirmarse sin temeridad que sea menos avanzada que otras que acogen distinta solución.

En el elenco de las fórmulas nacionales en la disciplina, que describe la Sentencia, destaca el caso español, pues "una Sentencia del Tribunal Supremo dictada en 1999 constató la inconstitucionalidad del artículo 47 de la Ley sobre el estado civil que ofrecía la posibilidad de hacer figurar la mención «madre desconocida" en el Registro del estado civil". El mecanismo empleado sobresale tanto por su naturaleza jurisprudencial, como porque abandona las más modernas perspectivas en la materia. En efecto, a la simple lista congelada de ordenamientos, el propio TEDH añade una reveladora tendencia: "estos últimos años se asiste en algunos países a una evolución hacia la aceptación, si no del parto anónimo, al menos de un parto discreto". En este sentido, se cita el caso de Bélgica y el de Alemania. En el primero resalta, junto al elevado "número de mujeres que pasan la frontera para parir en Francia en el anonimato", el debate abierto por el dictamen del Comité consultivo de bioética de 12 de enero de 1998: "algunos consideran que es inaceptable que vengan al mundo niños sin filiación; es por ello que prefieren proponer «el parto con discreción» no cerrando definitivamente la puerta a cualquier búsqueda de filiación. Otros piensan que el dilema ético planteado por el parto en el anonimato no reside en modo alguno en la oposición de los derechos respectivos «del niño a una filiación" y de "la madre desamparada» a resolver su situación conflictiva, sino en la confrontación más fundamental de los dos valores, el de la vida del niño, por un lado, y el derecho de toda persona a conocer a su madre biológica por otro. Señalan que, en este dilema, el primer valor a respetar es la protección de la vida del niño y su desarrollo. Es por ello que consideran que el parto en el anonimato es perfectamente legítimo y aceptable desde el punto de vista ético". En este punto reside, a mi juicio, el quid de la cuestión, cuyo planteamiento, tal y como se concibe aquí, me parece óptimo. Similiter ocurre con Alemania, donde, frente al aumento de recién nacidos abandonados, se instaló en varias ciudades el «buzón para bebés» (Babyklappe), sitio en el que la madre, tras depositar a su criatura, toca el timbre y abandona sin identificarse ${ }^{31}$. Aun cuando el Bundestag rechazó un proyecto de Ley relativo al parto anónimo (año 2002), después el Land de Bade-Wurtemberg sometió al Bundesrat otra moción legislativa semejante, a fin de promover de nuevo su aprobación parlamentaria.

\section{d) El affaire Odièvre: La Sentencia}

Hechas estas aclaraciones previas acerca de los instrumentos jurídicos de análisis sobre la cuestión debatida, interesa centrar el estudio en el contenido

${ }^{31}$ Otro ejemplo constituye Hungría, pues la madre alcanza su anonimato si deposita en una sala especial no vigilada en los hospitales a su recién nacido. 
de la decisión del TEDH. Para ello se seguirá el esquema de los derechos vindicados en la demanda.

Este tránsito al fondo del asunto Odièvre, supera la excepción preliminar del Gobierno francés por no haberse agotado los recursos internos en su país. La defensa fue rechazada por unanimidad no mantenida para el resto de los pronunciamientos. Una vez despejado el camino, el Tribunal accede al examen del artículo 8 del Convenio -«1. Toda persona tiene derecho al respeto de su vida privada y familiar [...]»-, que constituiría el auténtico nervio de la cuestión.

La primera de sus dimensiones abordadas, y que no conservó en el curso del proceso su aparente carácter accesorio, es a qué tipo de intimidad se refería el caso, sostenida como familiar por la demandante y privada por el Gobierno francés. El TEDH la sitúa en el segundo plano -vida privada, no familiar-, habida cuenta que "la demandante no trata de cuestionar la existencia de su filiación adoptiva sino conocer las circunstancias de su nacimiento y de su abandono englobando el conocimiento de la identidad de sus padres biológicos y de sus hermanos". Ahora bien, ambas engloban "el establecimiento de los detalles de su identidad de ser humano y el interés vital, protegido por el Convenio, en obtener informaciones necesarias para el descubrimiento de la verdad sobre un aspecto importante de su identidad como, por ejemplo, es el de la identidad de sus progenitores (Sentencia Mikulic contra Croacia, núm. 53176/1999, 7-2-2002, aps. 54 y 64). El nacimiento, y singularmente las circunstancias de éste, depende de la vida privada del niño, luego adulto, garantizada por el artículo 8 del Convenio que, por tanto, se aplica en el presente caso". Resulta oportuno referir que dicho problema fue decidido por unanimidad, aunque con cierta discrepancia de argumentos, como consta en el voto disidente de la minoría.

A partir de aquí, "el Tribunal recuerda que, aunque el artículo 8 tiende en lo esencial a prevenir al individuo contra injerencias arbitrarias de los poderes públicos, no se contenta con exigir al Estado que se abstenga de dichas injerencias: a este compromiso más bien negativo pueden añadirse otras obligaciones positivas inherentes al respeto efectivo de la vida privada". Es decir, que incluso una simple abstención de los poderes públicos en la materia no garantiza de suyo el cumplimiento de las exigencias derivadas del Convenio. La vida privada puede imponer conductas a los organismos oficiales para su necesaria defensa, si bien se acaba reconociendo que "la frontera entre las obligaciones positivas y las negativas del Estado en virtud del artículo 8, no se presta a una definición precisa".

La Sentencia declara que, para una certera decisión del asunto que se somete a su criterio, "hay que tener en cuenta el equilibrio justo a mantener entre los intereses opuestos; asimismo, en las dos hipótesis, el Estado goza de un cierto 
margen de apreciación" (cfr. Sentencia Mikulic, ap. 58). Tanto el principio de proporcionalidad de los intereses en juego como el margen de apreciación de cada Estado constituyen los aspectos más discutidos y, a la postre, decisorios para el Tribunal. Su controversia se vierte no sólo en la opinión discordante suscrita por la minoría de siete miembros, sino incluso en las tres opiniones concordantes mantenidas por cuatro miembros de la mayoría. Es muy revelador que ambas tendencias coincidan en este punto, aunque con resultados muy dispares, pues hubiera podido articular una holgada decisión de once jueces. Todos señalan que la Sentencia no incide lo suficiente sobre la concreta justificación del principio de proporcionalidad que se alude. Los segundos en su debida defensa y los primeros para negarla de plano, según el partido que adoptan en el voto. Asimismo, sendos grupos discrepan en orden al margen de apreciación del Estado, reduciéndolo mucho éstos y ampliándolo aquéllos, con arreglo a la jerarquía que mantienen para los intereses enfrentados. A mayor preponderancia de alguno de los polos, la libertad jurídica en su disciplina se comprime, sucediendo al revés si crece la consideración de su equilibrio efectivo, que confiere al Estado amplia capacidad de maniobra. El desarrollo y debate concreto de las tesis esgrimidas en este punto se une al examen de los votos particulares.

Con tales axiomas, la demandante denuncia carencias en su vida privada, por cuanto el sistema jurídico francés obstaculiza de modo absoluto la búsqueda de la madre mientras ésta hubiese solicitado el secreto y, en especial, tampoco permite la comunicación de sus datos identificadores a través de organismos que faciliten el acceso a dicha información. A este respecto, recuerda el Tribunal, el ciudadano "tiene un interés primordial protegido por el Convenio en recibir informaciones que necesitan conocer, para comprender su infancia y sus años de formación". Ahora bien, ya en el caso Gaskin se autorizó el carácter confidencial de algunos expedientes oficiales, tanto para la garantía de su fiable contenido como por la protección de terceros. Luego "un sistema que subordina el acceso a los expedientes al consentimiento de los informadores [...] puede en principio ser considerado compatible con el artículo 8, teniendo en cuenta el margen de apreciación del Estado" (Sentencia Gaskin contra Reino Unido de 7 de julio de 1989, ap. 49; ver también Sentencia M. G. contra Reino Unido, núm. 39393/1998, 24-9-2002, ap. 27)32. Como puede apreciarse, una proporcionalidad calibrada de los intereses en concurrencia deja expedito el mayor margen de apreciación de cada Estado.

Aún así, teniendo en cuenta que se produce la cita de los precedentes alegados por la parte actora, el Tribunal también señala que las situaciones del señor

${ }^{32}$ Respeto en la cita de las Sentencias el doble y discutible modelo que propugna el Tribunal atendiendo a su fecha: las más recientes por el número y las anteriores por su datación. 
Gaskin $^{33}$ y de la señorita Mikulic ${ }^{34}$ eran distintas de la referida. La pretensión de conocer sus orígenes biológicos y la identidad de sus padres no es de análoga naturaleza que la del acceso al expediente personal sobre un niño acogido, o a la de la búsqueda de pruebas de una paternidad solicitada. El presente litigio se insta por una mujer adoptada en su día y hoy en pos de su madre biológica, quien solicitó expresamente la ocultación de dicho nacimiento. Ambas son personas maduras, con intereses protegibles en el marco del artículo 8 del Convenio, aun cuando desde un punto de vista ético no sean equivalentes sus actitudes. Por un lado, está el derecho a conocer los propios orígenes, cuyo fundamento estriba en una interpretación amplia de la vida privada, máxime cuando el interés de los menores es generosamente reconocido en la economía general del Convenio (ver, entre otras, Sentencias Johansen contra Noruega de 7 de agosto de 1996, ap. 78; o Kutzner contra Alemania, núm. 46544/1999, 262-2002, ap. 66). Por otra parte, no se puede desconocer el interés de una madre hacia el anonimato, que le permite alumbrar con atención médica satisfactoria y protege así su salud, viéndose libre de presiones externas e internas sobre su conducta o estado civil.

Al margen del conflicto que une a los directamente implicados por la relación física que se busca desvelar, existen indudables proyecciones del asunto en terceras personas. En este conjunto destacan los adoptantes y los demás miembros de la familia biológica, sobre todo padre y hermanos, que tienen igualmente derecho a ver incólumes su vida privada y familiar. El modo de conciliarse las diversas perspectivas del mismo derecho en correspondencia con sus distintos titulares y su relación con el problema enjuiciado no resulta fácil. La más equilibrada regla de compromiso indica que, sobre la base de reconocer cierto ámbito a la demanda, ello no comporte un daño en los intereses legítimos de la madre y, por supuesto, de terceros. Parece ser ésta la medida impulsada en la Sentencia, en cuyo sentido, "el Tribunal señala que la demandante tuvo acceso

\footnotetext{
${ }^{33}$ Quien padecía males psicológicos a causa de los maltratos que consideraba inferidos mientras era pupilo de las instituciones de asistencia pública, y que solicitó el acceso a su expediente, custodiado por los servicios sociales.

34 "En el asunto Mikulic, la demandante, una niña de cinco años, se quejaba de la lentitud del procedimiento de búsqueda de paternidad iniciado junto a su madre y de la inexistencia en derecho croata de medidas procesales que permitan a los tribunales obligar «al padre» a someterse a las pruebas de ADN ordenados por los jueces. El Tribunal sopesó el interés vital de los individuos en obtener informaciones necesarias para el descubrimiento de la verdad sobre un aspecto importante de su identidad personal y el interés de terceras partes en negarse a someterse a un examen médico. Consideró que el Estado estaba obligado a establecer medios alternativos que permitieran a una autoridad independiente resolver la cuestión de la paternidad en breve plazo. En ese caso, no se había respetado el principio de la proporcionalidad en relación a los intereses de la demandante, a la que se había abandonado en un estado de incertidumbre en cuanto a su identidad personal (aps. 64-66)". Es de reconocer cómo la prevalencia de uno de los intereses contrapuestos (hija/padre) conduce a reducir el margen de apreciación estatal en garantía de su respeto.
} 
a informaciones no identificativas sobre su madre y su familia biológica que le permitieron establecer ciertas raíces de su historia dentro del respeto de la preservación de los intereses de terceros".

A la óptica de las partes interesadas en el litigio y de los ajenos directamente afectados por la circunstancia, debe añadirse otra perspectiva de indudable relieve. A juicio del Tribunal existe una proyección abstracta de los valores en juego, que se materializa en el caso debatido. La Sentencia reconoce presente asimismo el interés general "en la medida en que la Ley francesa se inscribe, desde hace tiempo, en el deseo de proteger la salud de la madre y del hijo durante el embarazo y el parto, y de evitar los abortos, en concreto los abortos clandestinos, o los abandonos "salvajes». El derecho al respeto a la vida, valor superior garantizado por el Convenio, no es de esta forma ajeno a los fines que persigue el sistema francés". Aquí radica uno de los elementos fundamentales de análisis, que no se puede circunscribir a los hechos sin unas mínimas consideraciones sobre su modo de producirse. Una vez nacida la criatura, sin duda su pretensión en el conocimiento de su familia biológica tiene un notorio alcance jurídico, muy por encima de la mera garantía de la intimidad de la madre, mas el proceso no debe acotarse así. Las conclusiones efectistas resultan un atajo simplista, pues no repara en que si a la madre se le impone hacer pública su identidad, acaso no lo llegue a ser nunca. En otros términos, los intereses de hijo y madre hallan un punto de convergencia en la salud física y mental de la segunda que facilita el nacimiento del primero. A falta de otros recursos, sería preferible vulnerar derechos personales distintos de la vida e inferiores a ella. La jerarquía en los valores se corresponde con la ordenación de los derechos que los reflejan. La salud de la progenitora y la seguridad en el parto constituyen la mejor salvaguardia de la vida del nasciturus. Poner en riesgo lo primero supone peligrar la existencia venidera.

Por tanto, se concluye "que Francia no ha excedido el margen de apreciación que le debe ser reconocido debido al carácter complejo y delicado de la cuestión que plantea el secreto de los orígenes en virtud del derecho de cada uno a su historia, de la elección de los padres biológicos, del vínculo familiar existente y de los padres adoptivos". Es decir, el carácter caleidoscópico de los intereses comprometidos, sus distintos titulares y trascendencia histórica en particular, concede a los Estados un amplio margen de apreciación, en cuyo seno se ubica el alumbramiento anónimo. Además, "el sistema establecido por Francia recientemente, aunque conserva el principio de la admisión del parto anónimo, refuerza la posibilidad de levantar el secreto de la identidad que, después de todo, existía antes de la aprobación de la Ley de 22 de enero de 2002. La nueva Ley facilitará la búsqueda de los orígenes biológicos gracias al establecimiento de un consejo nacional de acceso a los orígenes personales, órgano independiente [...], que permitirá desde ahora a la demandante solicitar 
la reversibilidad del secreto de la identidad de su madre siempre con el consentimiento de ésta, de forma que asegure equitativamente la conciliación entre la protección de esta última y la solicitud legítima de la demandante".

Junto al examen individualizado del artículo 8 del Convenio, también cita la demandante su relación con el artículo 14: "el goce de los derechos y libertades reconocidos en el [...] Convenio ha de ser asegurado sin distinción alguna, especialmente por razones de sexo, raza, color, lengua, religión, opiniones políticas u otras, origen nacional o social, pertenencia a una minoría nacional, fortuna, nacimiento o cualquier otra situación".

Es de añadir que, según la jurisprudencia del órgano ad quem, "el artículo 14 no hace sino completar las demás cláusulas normativas del Convenio o de sus Protocolos: no tiene existencia independiente ya que es válido únicamente para el "goce de los derechos y libertades» que éstas garantizan". En este sentido, "en el goce de los derechos y libertades reconocidos en el Convenio, el artículo 14 prohíbe tratar de manera distinta, salvo justificación objetiva y razonable, a las personas que se encuentran en situaciones comparables (Sentencia Salgueiro Da Silva Mouta contra Portugal, núm. 33290/1996, 21-12-1999, ap. 26)".

A la vista de la ordinaria proyección jurídica del principio de igualdad en el marco del Convenio, la parte actora denuncia la discriminación que sufre por las "restricciones a su capacidad de recibir bienes de su madre natural cualquiera que fuese la compensación que pudiera resultar por el hecho de su adopción". Es decir, aun cuando consolide las expectativas hereditarias ex adoptione, considera que se ve privada de los derechos que pudieran corresponderle por vía natural de su madre, frente a lo que ocurre con sus hermanos de sangre, que conservaron sus vínculos de parentesco.

A ello se opone la demandada, porque "no existe, en opinión del Gobierno, ninguna diferencia de trato en el presente caso. El niño abandonado por su madre no se encuentra en una situación comparable a la de los demás niños que son asumidos por sus padres. Solamente una diferencia de trato entre los niños nacidos en las condiciones previstas por el artículo 341.1 del Código Civil podría conducir a la crítica". Desde luego, el argumento de la igualdad restringida en su ámbito a la filiación de idéntica naturaleza es harto discutible y hasta parece advertirlo el propio aducente, pues, como hipótesis, considera que dicha diferencia de trato estaría justificada por los fines del precepto y la proporcionalidad de medios esgrimidos en su logro. Sin embargo, no resulta menos cierto que los vínculos de adopción colman las expectativas sucesorias ${ }^{35}$.

\footnotetext{
${ }^{35} \mathrm{El}$ alegato de la demanda en este punto parece más una excusa que otra cosa. Ya se narraron las condiciones en que se produjo el abandono y el estado de grave penuria que lo propició. A su vez, la familia de acogida tuvo de garantizar en el proceso adoptivo un nivel económico del que, por desgracia, carecía la de origen. La repercusión patrimonial de todo ello más beneficia que perjudica los derechos de la parte actora.
} 
Además, es idea común que la nueva familia de adopción sustituye a la natural y extingue los lazos de sangre ${ }^{36}$, incluidos los hereditarios.

Ante los términos de la controversia, el Tribunal considera que la solicitud en la práctica coincide, si bien vista desde un ángulo distinto, con la ya examinada sobre la base del artículo 8 del Convenio. A efectos útiles, se juzga que no se produjo ningún trato discriminatorio, debido a la condición de la demandante. Por un lado, dispone de nuevos vínculos respecto a sus padres adoptivos con un componente patrimonial que sustituyen a los naturales, $y$, de otro, no puede pretender, en referencia con su madre biológica, un status equivalente a la de sus hermanos con filiación originaria establecida, máxime cuando se acumularía con el sobrevenido por adopción.

\section{e) El affaire Odièvre: Crítica}

recibida interna y externamente por la Sentencia

Como digo, el fallo establece por diez votos contra siete que no hay violación de los artículos 8 y 14 del Convenio. Cuatro de los magistrados hicieron pública su opinión favorable con matices y siete su disenso. El examen de la fuerte resistencia interna que soporta la decisión ayuda también a calibrar mejor sus fundamentos, sobre todo en lo relativo a la proporcionalidad de intereses y al margen de apreciación, ya mencionados.

En cuanto a los razonamientos concordantes, el Sr. Roizakis comparte totalmente la conclusión de la mayoría de la Gran Sala, pero desea incidir en el plano argumentativo. A su parecer, "el Tribunal concede demasiada importancia a este aspecto concreto del margen de apreciación [...] en lugar de mostrar que ha establecido un equilibrio justo y satisfactorio entre el margen de apreciación limitado ("cierto» margen de apreciación) que dispone Francia y el criterio de necesidad (necesaria en una sociedad democrática) que es, en mi opinión, el criterio fundamental a aplicar en las presentes circunstancias". Es decir, el Tribunal ha hecho un examen profundo de los intereses enfrentados y su relativo valor, lo que de por sí fortalece la solución adoptada, incluso con independencia y por encima del margen de maniobra reconocido a los distintos Estados.

En esta línea, más sustantiva que formal respecto del fallo, se mueve la opinión concordante del Sr. Ress -a la que se suma el Sr. Küris-, según los cuales "ciertamente es en el interés general que se adoptan las medidas adecuadas para mejorar la situación de las madres desamparadas y proteger la vida del niño, es decir disminuir lo más posible el número de abortos, oficiales o clandestinos", sin perjuicio de que otros países tomen otro tipo de medidas también aceptables. Luego "este proceder responde también muy concretamente al profundo

\footnotetext{
${ }^{36}$ Para el caso español, cfr. artículos 160 y 178 del Código Civil.
} 
desamparo de la madre, aunque y justamente la madre no tenga en mente el aborto", "pero no se excluye, sino que es más bien probable, que una mujer en tal situación recurriera más bien a un aborto, tanto legal como clandestino, para evitar enfrentarse a los inconvenientes y a la responsabilidad moral que se derivan de dicho nacimiento". Por tanto, "el deseo del Estado de proteger la vida y de reducir el número de interrupciones voluntarias del embarazo, que son en principio consideradas en algunos países del Consejo de Europa -por ejemplo en Alemania- «ilegales», aunque el Estado no prevea, en el primer período del embarazo, medidas en derecho penal para evitar dichos abortos, es un fin legítimo". Sin perjuicio incluso de que haya estabilidad en el número de abortos, "no excluye que el Estado prevea medidas de interés general para reducir dicho número". En fin, "no nos encontramos solamente frente a un conflicto entre el derecho del niño a conocer sus orígenes y el interés de la madre a conservar el anonimato. También estamos frente al interés del Estado en prever una solución para las madres desamparadas y en proteger al mismo tiempo la vida de los niños por nacer. Sería demasiado simple reducir este conflicto solamente a la relación entre la madre y el hijo tras el nacimiento de éste". "El individuo que trata de levantar el secreto a cualquier precio, incluso contra la voluntad expresa de su madre natural, debe preguntarse si su nacimiento habría tenido lugar sin el sistema del parto anónimo". Según puede observarse, inciden de lleno y directamente sobre los valores aducidos por los protagonistas del conflicto, como prueba el debate abierto en este punto por el sector disidente.

A esta tendencia se incorpora también la Sra. Gréve, que considera inmejorable que todos tengan acceso a su origen biológico, aunque "las circunstancias de la vida no permiten siempre, sin embargo, que las cosas sucedan de forma ideal". Acto seguido enfrenta una de las refutaciones del grupo minoritario: hasta escaseando los supuestos reales, como se afirma, el método de los grandes números repugna para la criba del riesgo abortivo, que siempre afecta sobre personas. Estos problemas resisten análisis cuantitativos y reclaman más bien los cualitativos. El método aritmético, que arguye la minoría discordante, deviene inútil: "ni los cambios en el número de abortos, ni algunas menciones de las razones que empujan a abortar, ayudan. Lo único cierto estadísticamente, es que sigue habiendo cada año cierto número, sin duda escaso, de nacimientos clandestinos con abandono de niño, que constituyen otras tantas tragedias humanas". Estima que la presente doctrina es continuista con la jurisprudencia del TEDH sobre la cuestión, cuyo satisfactorio juicio atiende al caso en particular con sus dimensiones humanas y busca "permitir a la madre dar a luz en las mejores condiciones de seguridad con la ayuda de médicos, aunque se negara a dar su nombre y sus señas de forma que dicha información pudiera ser divulgada posteriormente sin su consentimiento, y tomó la decisión irrevocable de abandonar a su hijo. En mi opinión, esta decisión del Estado respeta 
los derechos de la madre y del hijo antes del nacimiento", pues "el derecho a la vida prevalece sobre cualquier otro; en efecto, todos los demás derechos consisten en conferir cierta calidad a la vida. Ello vuelve a poner en su contexto a los dos intereses opuestos del niño. El principal interés de éste es el de nacer, y ello en condiciones en las que la salud no se ponga inútilmente en peligro porque su madre trata de dar a luz en secreto". "Se diga lo que se diga, el aborto representa como mínimo un problema ético y ninguna sociedad debería verse obligada, en nombre de la defensa de los derechos humanos, a no dejar otra opción que la del aborto a una mujer para garantizar su seguridad. El aborto clandestino puede hacer peligrar la salud, si no la vida de la madre. Antes del nacimiento, los intereses de la madre y los del niño son esencialmente convergentes". Además, "el embarazo no es una enfermedad. Actualmente en Europa, el embarazo no representa en el mejor de los casos sino una prueba física para la madre y el niño, pero el parto requiere a menudo una asistencia médica de la que no se puede prever en qué caso será innecesaria": "la negativa a facilitar a una mujer embarazada una asistencia médica incondicional-por más que se traten de condiciones que no sean médicas- puede, en mi opinión, dar lugar potencialmente a una violación de los artículos 2 y 3 del Convenio". En fin, "una mujer embarazada que se encuentre en una situación difícil -lo que sucede en el presente caso y en el de las mujeres que actualmente eligen dar a luz en el anonimato- debería poder traer al mundo a su bebé con total seguridad para ella y el niño, y éste debería poder conocer la identidad de su madre aunque fuese inmediatamente adoptado por otra familia. Sin embargo, cuando una mujer no puede recurrir a esta posibilidad por el motivo que sea -y puede resultar difícil para cualquier persona que no sea ella el juzgarlo plenamente- los derechos humanos exigen no obstante que pueda dar a luz con total seguridad para ella y para el niño, aunque insista en conservar su anonimato respecto a este último. Sería evidentemente inhumano invocar los derechos humanos para obligar a una mujer en dicha situación a escoger entre un aborto y un parto clandestino, soluciones que llevan siempre consigo un riego potencial para la salud de la madre y/o del niño y, en el peor de los casos, un riesgo para la vida, y/o que pueden llevar al nacimiento de un bebé muerto".

Contra estas opiniones, se alzaron las del voto disidente de los Sres. Wildhaber, Bratza, Bonello, Loucaides, Cabral Barreto, Pellonpää y de la Sra. Tulkens. En el fondo, se observa que la falta de sintonía es más de criterios valorativos y no tanto de planteamiento, fuentes, etc. También asumen el conflicto axiomático: "a saber, por un lado, el derecho del niño a tener acceso a sus orígenes y, por otro lado, el derecho de la madre a conservar en secreto su identidad en cuanto al nacimiento, por un cúmulo de motivos que le pertenecen y dependen de la autonomía personal. Además, entran en juego otros intereses como, concretamente, el deseo de proteger la salud de la madre y del niño durante el embarazo 
y el parto o incluso la necesidad de prevenir los abortos o los infanticidios". Ante dicho dilema, concluyen que "la Ley admite, como obstáculo absoluto a cualquier búsqueda de información emprendida por la demandante, la decisión de la madre, cualquiera que fuese el motivo o la legitimidad de dicha decisión". A su juicio, ello implica que "la madre dispone así de un derecho puramente discrecional de traer al mundo a un niño a sufrir y condenarle, de por vida, a la ignorancia. No se trata, por tanto, de ninguna manera de un sistema mixto que asegura cierto equilibrio entre los intereses en cuestión ${ }^{\prime \prime}{ }^{37}$. Incluso vuelven al revés el argumento de la mayoría y opinan que "la madre puede, de igual forma, paralizar los derechos de terceras personas, concretamente los del padre biológico o los de los hermanos o hermanas, que pueden verse también privados de sus derechos garantizados por el artículo 8 del Convenio". Es decir, suponen -con dudoso éxito, me parece- que averiguar a posteriori la existencia de una congénere luego abandonada, lejos de perjudicarles, incluso les beneficia. Quién sabe, porque tampoco nadie les pregunta: en la hipótesis de que se obligue a la madre a reconocer su identidad, ellos quedan desvelados a un tiempo.

En otra línea, refutan como decisivo el dato de que la demandante fuese adoptada en su día, teniendo en cuenta que "se ha demostrado que los niños adoptados experimentan a menudo como una forma de deber la búsqueda de sus padres biológicos. El niño, incluso adoptado, que no puede acceder a sus orígenes familiares, de la forma que sea, es puesto en una situación de sufrimiento de la que corre el riesgo de padecer secuelas". Asimismo, el sector disidente niega "el riesgo de aumento de abortos, incluso de infanticidios, en la hipótesis de que se suprimiese el parto anónimo", tanto por falta de prueba estadística, como de la experiencia en países donde falta el parto anónimo. Además, "el desarrollo de la contracepción y de la planificación familiar tienen una relevancia considerable en la paternidad responsable".

Sin embargo, el nervio decisivo de su crítica se centra en el margen de apreciación de "que dispone el Estado en la elección de las medidas adecuadas para garantizar el cumplimiento del artículo 8 [...] margen que se vería reforzado por la diversidad de sistemas y tradiciones jurídicas". Entiende la minoría que tal abanico de posibilidades resulta muy escaso: "estamos firmemente convencidos de que el derecho a la identidad, como condición esencial del derecho a la autonomía (Pretty contra Reino Unido, Sentencia de 25 de abril de 2002, ap. 61) y al desarrollo (Bensaïd contra Reino Unido, Sentencia de 6 de febrero de 2001, ap. 47), forma parte del núcleo duro del derecho al respeto de la vida privada. Por lo tanto, se impone un examen aún más elevado para sopesar los

${ }^{37}$ El argumento contrasta enormemente con el permisivismo manifestado frente a otras fórmulas relativas a la fecundación artificial y los derechos de la "mujer sola", que, con mayor crudeza y menos motivos diría yo, impone anonimatos de progenitores. 
intereses en cuestión". Refuerza este modo de ver las cosas que gran parte de los países signatarios no reconozcan el parto anónimo, e incluso contemplen el derecho a conocer el origen biológico como integrante de los derechos de la personalidad. Así ocurre con la Sentencia de 31 de enero de 1989 del Tribunal Constitucional federal alemán, la Constitución federal Suiza desde 1992, y en los Países Bajos desde la Sentencia Valkenhorst del Tribunal Supremo de 15 de abril de 1994. A ello se añaden distintos documentos internacionales en la materia: "el Convenio internacional relativo a los Derechos del niño de 20 de noviembre de 1989 dispone que el niño tiene desde el momento de su nacimiento «en la medida de lo posible, el derecho a conocer a sus padres» (artículo 7). Asimismo, el Convenio de La Haya de 29 de mayo de 1993 sobre la protección de la infancia y la cooperación en materia de adopción internacional, ratificado por Francia, prevé que las autoridades competentes del Estado Contratante velen por la conservación de las informaciones en su poder sobre los orígenes del niño, concretamente las relativas a la identidad de la madre y del padre [...]. Aseguran el acceso del niño o de su representante a estas informaciones con el asesoramiento adecuado, en la medida permitida por la Ley de su Estado (artículo 30). En una Recomendación de 26 de enero de 2000 «Para el respeto de los derechos del niño en la adopción internacional», la Asamblea parlamentaria del Consejo de Europa invita a los Estados «a asegurar el derecho del niño adoptado a conocer sus orígenes como muy tarde en su mayoría de edad y a eliminar de su legislación interna cualquier disposición en contrario»". Por último, rechazan la diferencia establecida entre los casos Gaskin y Mikulic y el presente, cuyas similitudes bien hubieran permitido acoger la demanda. "En definitiva, contrariamente a la mayoría, consideramos que la legislación francesa no ha mantenido, en las circunstancias de la causa, un equilibrio justo entre los intereses en cuestión y que el artículo 8 del Convenio ha sido violado".

Este debate no sólo ha producido sus frutos en la esfera interna del Tribunal. Los primeros comentarios de la doctrina española sobre la sentencia destacan por su profunda crítica. Es el caso del Profesor Rivero, quien, con su ya conocida pericia y nutrido aparato crítico, emprende la tarea. Reconozco que dicho autor es uno de los principales especialistas españoles en Derecho de filiación, pero me voy a permitir la osadía de discrepar de su muy autorizado criterio. Además, mi disidencia no sólo es de opinión, sino que también se dirige a los presupuestos de su análisis. Quizás su cercanía con el tema le haya inducido a permitirse algunas licencias que yo considero excesivas ${ }^{38}$, sobre todo en cuanto

\footnotetext{
${ }^{38}$ Sin embargo -en sus propias palabras, que yo suscribo-, el gran obstáculo de la materia estriba en la vehemencia con que se aborda de ordinario (cfr. Rivero, "De nuevo", cit. nota n. 10, p. 598). Mas, a mi juicio, lejos de conjurar el peligro acaba en él. Así, descalifica el "riesgo de aborto o de infanticidio", como argumento sin verdadera enjundia y trasnochado, que relega en su estudio a su menor relieve, aunque la Sentencia del TEDH lo destaque, posiblemente mucho más
} 
a su enfoque. Sin duda existe por su parte una opinión previa, ya publicada y esgrimida, cuyo prejuicio condiciona el estudio ${ }^{39}$. Su punto de partida -que sea el conflicto de intereses "habitual en todo fenómeno y problema jurídico"resulta intachable, por lo que "lo importante ahora es encontrar una correcta ponderación de aquellos intereses para que triunfe y sea protegido el más valioso", "con exquisito respeto al principio de proporcionalidad, que tiene aquí un importante juego" ${ }^{\prime \prime}$.

A partir de aquí, desarrolla fundamentalmente las ideas vertidas en la opinión de la minoría discrepante, de modo que juzga "el riesgo de infanticidio o aborto (...) es hoy bastante menor que en otros tiempos, no sólo por los medios contraconceptivos que permiten evitar el embarazo y despenalización del aborto" ${ }^{\prime 4}$. Yo mantengo algunas reservas sobre sus visos de verosimilitud. La estadística señala un crecimiento en el número de abortos, compatible incluso, frente a lo que pudiera imaginarse, con la extensión de medios anticonceptivos (me refiero a términos absolutos, claro está). En todo caso, tratándose de criaturas nacidas, de cuyo conocimiento sobre su origen biológico se discute, causa cierto asombro que se alegue la contraconcepción, incompatible por hipótesis con un ser alumbrado. Igualmente, afirmar que la despenalización de las interrupciones del embarazo reduce su práctica resulta contradictorio en sí mismo. Por último, también parece discutible hacer idéntico el riesgo de aborto para las filiaciones matrimoniales o no; y ello, sin incidir en la práctica del abandono de niños, aún vigente a juzgar por las noticias periodísticas. Se dirá que desconocimiento y abandono se aproximan mucho, pero no es así: una cosa es desligarse de un recién nacido con plenas garantías de subsistencia, y otra exponerle a los peligros, a veces fatales y siempre inciertos, que comporta el desamparo en lugares públicos.

de cuanto desearía: "últimas ideas, ni nuevas, se esgrimen todavía con vehemencia en el debate doctrinal, e incluso en la Sentencia Odièvre" (ibidem, p. 598). En este sentido, no sorprende que afirme con tono algo dogmático que "la maternidad, el riesgo de aborto, el sentido del honor son hoy muy distintos de los de hace sólo unas décadas" (RIvero, "De nuevo", cit. nota n. 10, p. 599). Como botón de muestra, cabe proponer su cita de "lobbies pro adopción" (RIVERO, "De nuevo", cit. nota n. 10, p. 629) para explicar la Sentencia de Estrasburgo comentada, lo que me resulta exagerado e injusto, pues qué diría si alguien justifica la Sentencia del Tribunal Supremo español de 21 de septiembre de 1999 como abducida por grupos de presión abortistas, máxime si no hay pruebas que lo sustenten. En suma, su firme adhesión al voto particular de la minoría pertenece a su libre albedrío, siempre respetable, pero acaso no lo sea tanto el tratamiento que hace de las distintas opiniones barajadas en el pleito, al margen de su objetivo relieve para el fallo. A menudo me choca el silencio hacia el contenido textual de la Sentencia y no digo ya de los votos concordantes de la mayoría.

${ }^{39}$ Cfr. Rivero, Francisco, “¿Mater semper certa est? Problemas de la determinación de la maternidad en el ordenamiento español", Anuario de Derecho Civil, 1997, pp. 5 y ss.

${ }^{40}$ Cfr. Rivero, "De nuevo", cit. nota n. 10, p. 599.

${ }^{41}$ Cfr. Rivero, "De nuevo", cit. nota n. 10, p. 628. 
Existen altas posibilidades de perder la perspectiva cronológica del asunto con planteamientos de dicha especie. Por decirlo de alguna manera, parecen invertirse los valores y principios implicados cuando se juzgan hasta cierto punto a posteriori, como si se tratara de los intereses exclusivos de la madre, que quiere permanecer oculta para huir de la infamia y el descrédito social por haber dado a luz extramatrimonialmente, contra los del hijo, ya nacido, a conocer su origen biológico, con los derechos anejos que comporta ${ }^{42}$. En tales términos, sería muy cerril no aceptar la preponderancia del interés menos favorecido, que siempre representa la prole. Mas el conflicto surge de antemano, y entonces la pugna está en exponer al nasciturus a la incertidumbre, obligando a la madre a soportar una situación extrema, o que prospere con ciertas limitaciones jurídicas en el futuro. En tales hipótesis extraordinarias, no rigen planteamientos de antinomia entre los derechos de los hijos y de la madre y, si se me apura, entre los intereses que ambos detentan.

Antes se recogió la opinión de algunos jueces del TEDH que alertaban del incremento de abortos inducidos por autorizarse un acceso indiscriminado a la identidad de los progenitores, al margen de coyunturas excepcionales. No considero que sea éste un problema de quantum, sino de quale, pues el solo riesgo de una desgracia concreta, que se traduzca en la pérdida prematura de la vida en curso, debería inducir a la reflexión. Luego queda excluido del imperio de la ley de los grandes números, fuera de los modelos standard. En fin, se busca proteger a los protagonistas en su atributo más elemental: la subsistencia. El Profesor Rivero extrae los datos que aportó Francia en el litigio: existen en ese país cuatrocientas mil personas bajo dicha situación (neés sous $X)^{43}$. Tampoco es que su actual práctica indique un desuso del abandono infantil, hecho agudizado por las situaciones angustiosas de pobreza y explotación a que dan lugar ciertas avalanchas inmigratorias, si hemos de atender a la crónica de sucesos. Este panorama no admite la óptica distante de lo académico, sino que aboga por otro género de medidas, aunque técnicamente sean menos felices. A veces lo mejor es enemigo de lo bueno.

III. EL ANONIMATO RECONOCIDO AL DONANTE DEL ESPERMA:

la Sentencia del Tribunal Constitucional español de 17 de Junio de 1999

Existe todavía otro elemento de análisis acerca de la doctrina del anonimato del progenitor. La tesis maximalista que impulsa el Tribunal Supremo contra la

${ }^{42}$ Cfr. Rivero, "De nuevo", cit. nota n. 10, p. 598.

${ }^{43}$ Cfr. Rivero, "De nuevo", cit. nota n. 10, p. 596. Por tanto, reducir casi a la insignificancia el nacimiento de criaturas extramatrimoniales de madres casadas no parece muy verídico, máxime cuando el artículo 837, párrafo 2, del Código Civil, introducido en la reforma de 1981, contemplaba el supuesto antes de su reforma por Ley 15/2005, de 8 de julio. 
normativa del Registro Civil que autorizaba desconocer a la madre la filiación en determinadas condiciones, supone una verdadera ruptura con la sostenida por el Tribunal Constitucional apenas tres meses antes, permitiendo el secreto del padre.

En concreto, el Tribunal Constitucional hubo de resolver un recurso presentado contra el artículo 5 de la Ley 35/1988, de 22 de noviembre, sobre Técnicas de Reproducción Asistida. Esta disposición fue sustituida por la Ley 14/2006, de 26 de mayo, de Técnicas de Reproducción Humana Asistida, pero con idéntico tenor. La citada norma contempla las donaciones de gametos masculinos a fin de alcanzar la descendencia por medios artificiales. Como adujo la Exposición de Motivos de la originaria Ley, "la colaboración de donantes de material reproductor en la realización de estas técnicas supone la incorporación de personas ajenas a las receptoras y a los varones a ellas vinculados en la creación de los futuros hijos, que llevarán su aportación genética, con lo que se ponen en entredicho cuestiones del máximo interés relacionadas con el Derecho de Familia, la maternidad, la paternidad, la filiación y la sucesión; es necesario, por lo tanto, establecer los requisitos del donante y de la donación, así como las obligaciones, responsabilidades o derechos, si los hubiere, respecto de los donantes con los hijos así nacidos". El escenario descrito no podía ser más sincero, ni ajustado a la realidad. Nos encontramos en un panorama de intervención científica con repercusiones jurídicas que se desean asimismo moldear, incluso al margen de los axiomas jurídicos comunes en la materia. Hasta el modo de decir trasluce los afanes de los agentes externos cuando se habla de "la creación de futuros hijos".

El propósito que avala tales medidas sería "el respeto a los derechos de la mujer a fundar su propia familia". Luego "la Ley debe eliminar cualquier límite que socave su voluntad de procrear y constituir la forma de familia que considere libre y responsablemente". Es decir, la citada Exposición de Motivos y el texto que inaugura se irrogaba la licencia de romper todo tipo de barrera legal que frene los deseos, convertidos en derecho incondicionado, de las mujeres a ser madres. Mas no parece que la venia también abarque a la naturaleza jurídica de la maternidad así lograda, que se mantiene cualquiera sea el mecanismo de su consecución. Sin embargo, como la paternidad resulta en este proceso más bien accesoria -incluso se define como "colaboración de personas ajenas"-, el protagonista masculino queda exento de las cargas que se deriven de su aporte. Al fin, se varían los elementos naturales de la reproducción humana y a la par sus consecuencias jurídicas, de modo que "pueden la maternidad y la paternidad biológicas serlo también legales, educacionales o de deseo, y en tal sentido, es importante valorar cuál es la más humanizada, la más profunda en relación con el hijo, pues habida cuenta de las posibilidades y combinaciones que puedan darse, especialmente cuando en la gestación intervienen donantes 
de gametos u óvulos fecundados, los Códigos han de actualizarse sobre cuestiones determinadas que no contemplan".

En su virtud, el articulado de la Ley establece un horizonte con los siguientes puntos cardinales: la donación de gametos "es un contrato gratuito, formal y confidencial concertado entre el donante y el centro autorizado" (art. 5.1 LTRHA). Cualquiera diría que no es otro el padre sino el Banco de semen, hasta el punto que se le confía el uso de la información reservada sobre la identidad de progenitor auténtico, pero anónimo. La forma externa del acuerdo -divulgaciones aparte, dudoso contrato y menos donación, pues, aunque "nunca tendrá carácter lucrativo o comercial" (art. 5.3 LTRHA), "a la revocación procederá la devolución por el donante de los gastos de todo tipo originados al centro receptor" (art. 5.2, in fine, LTRHA)- desdice su naturaleza secreta. La expresión "por escrito" (art. 5.4 LTRHA) es aquí garantía de certeza -"los donantes habrán de ser informados de los fines y consecuencias del acto" (art. 5.4, in fine, LTRHA)y no principio de publicidad, máxime si "la donación será anónima y deberá garantizarse la confidencialidad de los datos de identidad de los donantes" (art. 5.5, pfo. 1, LTRHA).

Contra el esquema instaurado -que con simples variantes estilísticas conserva el nuevo texto- se alzó un recurso de inconstitucionalidad. Basaron su impugnación los promotores en diversos argumentos. Entresaco los más oportunos a los presentes efectos: "la finalidad, en principio loable, de la ley, terminaría por conducir a una sustancial alteración de la concepción de la familia y de los derechos de los hijos; al posibilitar la concepción por mujeres solas, manteniendo al padre - donante- en el anonimato. Ahora bien, la consideración de este problema debe partir de una idea fundamental: la técnica no prescinde, no puede prescindir, del padre biológico. Es cierto que junto a la paternidad biológica pueden existir otras legales, educacionales o de deseo, como también lo es que la institución de la adopción significa la sustitución de los vínculos de la familia originaria por los de la nueva familia en adopción. Pero en estos casos, la sustitución de la paternidad o maternidad biológica por otra legalmente determinada trata siempre de proteger el interés del hijo proporcionándole una familia legal. Por el contrario, opinan los recurrentes, el supuesto que nos ocupa no trata de proteger tal interés, sino lisa y llanamente de prescindir del vínculo biológico que une a la familia formada por padre, madre e hijo. En particular el conjunto institucional de las relaciones paterno-filiales constituye un haz de derechos y obligaciones generado desde el momento de la concepción y consolidado con el nacimiento del hijo, y que, en el sistema de la ley, desaparecería desde el momento en que se veda al hijo el conocimiento de quién sea su progenitor. Por ello, la ley resultaría claramente vulneradora del artículo 39.2 de la Constitución española, así como del contenido esencial de la protección de la familia a que alude el artículo 39.1". 
Sin embargo, "la solución legal, a juicio del Abogado del Estado, responde a criterios de razonabilidad en este conflicto de intereses", pues "la determinación de la paternidad cuando el gameto masculino procede de donante, cuyo anonimato protege la ley con alguna excepción (art. 5, N $N^{\circ}$ 5)", es "centro de un complejo conflicto de intereses: por un lado, el derecho de la persona a conocer su propia filiación biológica o sanguínea, que algunos autores (...) consideran como un derecho fundamental vinculado a la inviolabilidad de la persona; de otro, el derecho a la intimidad personal o familiar que corresponde a los padres jurídicos y la protección que el Estado debe dispensar a la estabilidad de las relaciones familiares; en fin, el derecho a la intimidad del donante" ${ }^{\prime 4}$.

Planteadas así las posturas, el dilema sobre la falta de correspondencia entre la verdad biológica y la filiación legalmente determinada no le ofrece dificultades de gran calibre al Tribunal. La excusa que apareja es, a mi juicio, altamente mejorable: constituye un "hecho comúnmente aceptado de que los hijos adoptivos se integren y constituyan una familia, aunque sus padres legales no se correspondan con los biológicos [véanse, en este sentido, las Sentencias del TEDH de 13 de junio de 1979 (asunto Marckx) 26 de mayo de 1994 (asunto Keegan v. Irlanda) y la de 27 de octubre de 1994 (asunto Catharina Kroon, Ali Zerrouk y Sami M'Hallem-Driss v. Países Bajos)]. No existe, por lo tanto, una obligada correspondencia entre las relaciones paterno-filiales jurídicamente reconocidas y las naturales derivadas de la procreación (SSTC 289/1993 y 114/1997)". Es decir, "las técnicas de reproducción asistida reguladas en la Ley no implican, por sí mismas, un menoscabo de su protección constitucional ni, por lo tanto, del principio establecido en el artículo 39.1 CE. Es por ello perfectamente lícito, desde el punto de vista constitucional, la disociación entre progenitor biológico y padre legal que sirve de fundamento a ciertas reglas contenidas fundamentalmente en los artículos 8 y 9 de la Ley".

Al margen de la simpleza y más que dudosa viabilidad de algunas razones esgrimidas -como hacer análogos los procesos adoptivos con otras faltas de sintonía, sobre todo las originarias, entre paternidad biológica y jurídica-, el mero contraste de dicha idea con la que arguye la Sentencia del Tribunal Supremo de 21 de septiembre de 1999 -tan sólo un trimestre después- siembra la inquietud. Ambas se ocupan del anonimato de los progenitores, pero la pri-

\footnotetext{
${ }^{44}$ El Abogado del Estado en su defensa del artículo estima el hipotético "derecho de la personalidad a conocer los propios orígenes" una simple tesis doctrinal, ni tan siquiera mayoritaria. Igualmente, contra cuanto luego declarará la Sentencia Odièvre, afirma que la intimidad familiar corresponde a los padres jurídicos y la personal al donante. La consecuencia es que permitir el anonimato paterno resulta factible a la vista del conflicto de intereses, como para la madre haría el Tribunal Europeo de Derechos Humanos. La idea puede ser debatida, pero carece de lógica su aceptación sectaria: sí en el primer caso, no para el segundo, como prospera en España. Incluso llegados al momento de preferir una de las opciones, yo escogería mejor a la madre, según los argumentos vertidos a lo largo del estudio presente, que afectan de inmediato al supremo bien del hijo.
} 
mera resuelve a favor del hombre mientras la segunda lo hace contra la mujer. La discriminación no puede ser más palmaria, con retorno a épocas anteriores felizmente superadas.

En todo caso, sería de agradecer siquiera el esfuerzo argumentativo de su decisión. Adoptar supone un remedio ex post frente a situaciones de abandono, que provoca indirectamente la quiebra entre paternidad biológica y jurídica, muchas veces por ignorancia de la primera, que se sustituye por la segunda. Sin embargo, ahora el fenómeno es distinto y más parece una fórmula ex ante y que produce de intento la ruptura entre ambas filiaciones, cuando no el desconocimiento de ambas en uno de sus protagonistas. Igualmente, qué decir de la salida ensayada para compatibilizar "el artículo 5.5 de la Ley: "La donación será anónima», con lo dispuesto en el artículo 39.2 de la Constitución, a saber: "La ley posibilitará la investigación de la paternidad»". "En efecto, la Constitución ordena al legislador que "posibilite» la investigación de la paternidad, lo que no significa la existencia de un derecho incondicionado de los ciudadanos que tenga por objeto la averiguación, en todo caso y al margen de la concurrencia de causas justificativas que lo desaconsejen, de la identidad de su progenitor. Pues bien, desde esta perspectiva, la Ley enjuiciada sólo podrá ser tachada de inconstitucional, por infringir lo dispuesto en el artículo 39.2 CE, en la hipótesis de impedir, sin razón o justificación alguna, la investigación de la paternidad". Es inconcebible que cuando la Constitución ordena con imperativo categórico que se posibilitará, pretenda luego el intérprete supeditarlo a siempre que sea ello factible, dependiendo además de circunstancias no expresadas en el máximo texto legal español, pues donde la ley no distingue no puede hacerlo su exégesis, y además la hermenéutica de las normas reconocedoras de derechos, como ésta, debe ser lo más amplia posible para sus beneficiarios.

Ahora bien, el concreto expediente intentado al propósito de hacer compatibles ambas normas produce asombro. El Tribunal Constitucional pretende "no olvidar, como base de partida, que la acción de reclamación o de investigación de la paternidad se orienta a constituir, entre los sujetos afectados, un vínculo jurídico comprensivo de derechos y obligaciones recíprocos, integrante de la denominada relación paterno-filial, siendo así que la revelación de la identidad de quien es progenitor a través de las técnicas de procreación artificial no se ordena en modo alguno a la constitución de tal vínculo jurídico, sino a una mera determinación identificativa del sujeto donante de los gametos origen de la generación, lo que sitúa la eventual reclamación, con este concreto y limitado alcance, en un ámbito distinto al de la acción investigadora que trae causa de lo dispuesto en el último inciso del artículo 39.2 de la Constitución". Es increíble cómo se da un vuelco al problema. Precisamente se denuncia que con el anonimato los hijos no podrán conocer la identidad de sus padres, y éstos quedarán exentos de todos los deberes para con su prole. Sin embargo, 
la Sentencia resuelve justo lo contrario, jamás pedido, por cierto: ya que la determinación biológica de la paternidad no trae consigo, según la ley, vínculo jurídico de ninguna especie, para qué hacerlo. Falacia completa: no se irroga deber alguno porque resulta imposible asumir la filiación, no viceversa, según se pretende. Gracias a semejante artificio, cualquier norma superaría el control de constitucionalidad, con sólo invertir los términos de la oposición.

Con todo, hay más. La Sentencia disculpa la regulación impugnada porque "el anonimato de los donantes que la Ley trata de preservar no supone una absoluta imposibilidad de determinar su identidad, pues el mismo precepto dispone que, de manera excepcional, "en circunstancias extraordinarias que comporten un comprobado peligro para la vida del hijo, o cuando proceda con arreglo a las leyes procesales penales, podrá revelarse la identidad del donante, siempre que dicha revelación sea indispensable para evitar el peligro o para conseguir el fin legal propuesto». Asimismo, el mencionado precepto legal atribuye a los hijos nacidos mediante las técnicas reproductoras artificiales, o a sus representantes legales, el derecho a obtener información general de los donantes, a reserva de su identidad, lo que garantiza el conocimiento de los factores o elementos genéticos y de otra índole de su progenitor. No puede afirmarse, por ello, que la regulación legal, al preservar la identidad de los donantes, ocasione consecuencias perjudiciales para los hijos con alcance bastante para afirmar que se produce una desprotección de éstos". Parece que la línea de razonamiento sigue rutas cada vez más insospechadas. Primero afirma que huelga determinar la filiación si no aporta efecto jurídico alguno, cuando esto último es lo que se recurre. Luego defiende que donde la ley ordena posibilitará quiere decir que lo hará en la medida en que nada obste. Por último, completa la ceremonia de la confusión con afirmaciones tales como que no es cierto que la prole quede desguarnecida de origen biológico, pues en el excepcional supuesto de peligro in actu para su misma vida o a causa del mandato inexcusable de disposiciones penales podrá desvelarse la identidad paterna, siempre que resulte necesario para los fines que se persiguen con tales medidas. Pocas veces se ha visto una fórmula legal tan férrea.

En efecto, el punto de partida está en las antípodas del descrito, y el anterior planteamiento implica subvertir el status quaestionis. La verdad biológica opera como principio básico en la materia, sólo dispensable si, atendidas las circunstancias, el peligro de la prole lo aconseja. Cuando la coyuntura sea extraordinaria cabe relajar la regla, pero constituye la norma el conocimiento de los progenitores y su licencia el anonimato. No obstante, la Sentencia comentada procede al revés, lo que resulta un buen indicio de su error. Además, es ilógico ceñir exclusivamente los riesgos de los hijos a las enfermedades de transmisión genética. Por este camino, sólo los descendientes con dicho factor de riesgo podrían acceder a su origen biológico. La falta de progenitores supo- 
ne por lo común una desgracia en las personas, tan sólo remediable por otros cauces como los adoptivos. Por tanto, nunca debería provocarse ab initio de manera intencionada por el desconocimiento de la filiación biológica, salvo que medien razones de peso avaladas ad casum; mas no por circunstancias genéricas o que beneficien al progenitor frente a la criatura, protagonista último del asunto. Es rechazable que para la fecundación asistida se haya partido de premisas contrarias. Un prudente silencio por el juzgador hubiera hecho menos lacerante la medida. En todo caso, que dicha óptica legal tenga excepciones contadísimas, y por motivos tan graves como poner coto a enfermedades de transmisión genética, no comporta ni de lejos que la pauta del anonimato quede amortiguada.

La incoherencia mostrada en el plano de las ideas encubre los verdaderos motivos de tan discutible apoyo al secreto del padre para las técnicas de fecundación asistida. Mas, a la postre, se termina por admitir, basándola en las necesidades perentorias del fomento de tales prácticas, fruto de un esfuerzo legislativo bajo el empuje de los avances biomédicos. Sin donante no hay técnica que valga, pero sólo con su exención de responsabilidades se facilitan los voluntarios. Ante dicho proceso no se responde con actitudes neutrales, sino que reclama un apoyo no escatimado. En términos de oportunismo político, afirma la Sentencia, "la finalidad primera y justificativa de la propia Ley que es, precisamente, la de posibilitar la fecundación y, por ende, la creación o el crecimiento de la familia como unidad básica y esencial de convivencia". Declaración de intenciones algo discutible, pues idéntico argumento se utiliza también para impulsar el aborto cuando los embarazos no se desean. Luego en un caso sirve para superar barreras naturales a la fecundación, mientras en otro cercena la vida del nasciturus. Ahora bien, el primer supuesto admite que pueda ser anónimo el padre, mientras que prevenir el segundo no sirve igual para la madre, aunque sea en beneficio de la criatura. Ello constituye, a mi juicio, un desacierto teórico, pero sobre todo una discriminación práctica de la mujer. Injusticia notoria, perpetrada, por paradoja, en nombre de la igualdad. ¿Qué se gana con el anonimato de donante de semen?: que haya esperma para fecundar; es decir, se fomenta la concepción asistida. Póngase frente al interés barajado en el secreto de la madre -que nazca el ya concebido-y la comparación brilla por sí misma. Todavía es menos aceptable un equilibrio de posturas de los progenitores desde la vertiente del afectado final. La madre asume un papel respecto de la filiación superior a la del padre y es más sensible a las situaciones extremas. Luego esta tesitura ni tan siquiera ofrece un equilibrio en las hipótesis de partida, por lo que su tratamiento jurídico es doblemente discriminatorio. El atropello se agudiza más teniendo presente los distintos roles que juegan ambos partícipes en el proceso de la fecundación humana y frente a la criatura ya nacida. Por eso me parece que mientras el anonimato de la madre puede aceptarse para 
determinadas situaciones, el padre no atraviesa por iguales condiciones en su descargo. Es decir, justo al revés de cuanto sucede ahora.

Todo ello se plasma en una verdadera movilización de recursos de argumentación jurídica que intenta el Tribunal Constitucional español. El anonimato del padre se defiende a la manera numantina: "Ios límites y cautelas establecidos en este ámbito por el legislador no carecen de base racional, respondiendo claramente a la necesidad de cohonestar la obtención de gametos y preembriones susceptibles de ser transferidos al útero materno e imprescindibles para la puesta en práctica de estas técnicas de reproducción asistida [orientadas - debe nuevamente recordarse- a fines terapéuticos y a combatir la esterilidad humana (art. 1.2 de la Ley)], con el derecho a la intimidad de los donantes, contribuyendo, de tal modo, a favorecer el acceso a estas técnicas de reproducción humana artificial, en tanto que situadas en un ámbito médico en el que por diversas razones-desde las culturales y éticas, hasta las derivadas de la propia novedad tecnológica de estos medios de fecundación- puede resultar especialmente dificultoso obtener el material genético necesario para llevarlas a cabo".

No me resisto a transcribir semejantes ideas sin hacer algún tipo de comentario. Comprendo que sostener una ruptura tan llamativa de los principios concernientes a la filiación en la necesidad de que tales técnicas perduren a base de partícipes exentos de responsabilidades resulta incómodo. Sin embargo, cuando se quiere reafirmar esta máxima con otros razonamientos auxiliares sus carencias se hacen patentes. El recurso de constitucionalidad precisamente se ocupa de si el anonimato paterno es admisible a la vista del artículo 39 de la Constitución, que contempla sin cortapisas la libre búsqueda de la paternidad. Es, por tanto, impropio que alegue la Sentencia como axioma "el derecho a la intimidad de los donantes". Eso es justo lo que debería discutirse: si hay derecho a la intimidad de los donantes, eufemismo que oculta el anonimato del padre. El hecho supone una petición de principio flagrante. Me gustaría saber dónde radica el pretendido derecho a la intimidad de los donantes de semen en cuanto tales y por qué se admite de antemano, hurtándolo al debate, al menos en su significación exacta. Como personas individuales no me ofrece su derecho a la intimidad duda de ninguna especie, pero no tanto en su faceta de padres efectivos por vía de fecundación artificial, o cualquier otra. Parece un exceso y un abuso que tu intimidad impida ser conocido por tu descendencia, máxime si el ordenamiento español no reconoce un derecho incondicionado y absoluto a la intimidad ${ }^{45}$.

${ }^{45}$ Cfr. artículos 2 ("1. La protección civil del honor, de la intimidad y de la propia imagen quedará delimitada por las leyes y por los usos sociales atendiendo al ámbito que, por sus propios actos, mantenga cada persona reservado para sí misma o su familia. - 2. No se apreciará la existencia de intromisión ilegítima en el ámbito protegido cuando estuviere expresamente autorizada por Ley o cuando el titular del derecho hubiere otorgado al efecto su consentimiento expreso, o, por imperativo del artículo 71 de 
A la postre, defender que "estas técnicas de reproducción asistida" están "orientadas a fines terapéuticos y a combatir la esterilidad humana (art. 1.2 de la Ley)", excede la lógica, si bien no carece la idea de cierto atractivo efectista, por su indudable alcance práctico. La fecundación asistida no es un remedio terapéutico de la esterilidad, que supone un impedimento para concebir, pues la mujer será infértil tanto antes como después, aunque haya dado a luz. La prueba está en que si desea más descendencia será patente la falta de cura. La Ilamada reproducción asistida no es un tratamiento de la esterilidad, pero resuelve sus perniciosos efectos mediante fórmulas alternativas. Hay personas perfectamente fecundas que no tienen descendencia y ahora también al revés; en su caso, el hijo se produce, pero sin que sane la infertilidad. Nadie afirma que los adoptantes dejen de ser estériles si antes lo eran y aquí radica el marco de comparación que plantea la propia Sentencia. En el fondo, infecundidad y reproducción asistida no tienen por qué corrresponderse. Una vez que los fines terapéuticos se ven desbordados ${ }^{46}$, sería bueno averiguar qué combate se libra contra la esterilidad cuando la Ley admite la fecundación de mujeres solas ${ }^{47}$. No creo que solucione una esterilidad ni tan siquiera comprobada, por simple falta de cópula. Según este argumento, toda mujer que no mantenga relaciones sexuales sería estéril por hipótesis. Sobran, creo, más comentarios, pero una Sentencia del Tribunal Constitucional español no debería incurrir en dichas ligerezas, sobre todo tratándose del derecho de los hijos a conocer a sus padres.

En cambio, "favorecer el acceso a estas técnicas de reproducción humana artificial, en tanto que situadas en un ámbito médico en el que por diversas

la Constitución") y 8 ("1. No se reputará, con carácter general, intromisiones ilegítimas las actuaciones autorizadas o acordadas por la Autoridad competente de acuerdo con la ley, ni cuando predomine un interés histórico, científico o cultural relevante") de la española Ley Orgánica 1/1982, de 5 de mayo, de protección civil del derecho al honor, a la intimidad personal y familiar, y a la propia imagen.

${ }^{46}$ Todo indica que a través del eufemismo se busca concitar adhesiones. Ofrece un buen ejemplo la utilización del test del hámster, que se autorizó en la originaria Ley "para evaluar la capacidad de fertilización de los espermatozoides humanos hasta la fase de división en dos células del óvulo del hámster fecundado, momento en que se interrumpirá el test" (14.4, in initio). No sé si vale la pena crear híbridos, aunque sólo en su primera fase, de hombre y rata para conocer la fecundidad del esperma humano, utilizado para fecundar roedores (aunque sean de laboratorio). El nuevo texto es todavía más generoso y su Anexo admite como "diagnósticos" los "Procedimientos dirigidos a evaluar la capacidad de fecundación de los espermatozoides humanos consistentes en la fecundación de ovocitos de animales hasta la fase de división del óvulo animal fecundado en dos células, momento a partir del cual se deberá interrumpir la prueba". Parece inaudito que un escenario tan de ciencia ficción sean normas jurídicas aplicables en España.

${ }^{47}$ Con arreglo al artículo 6.1, in initio, LTRHA, "toda mujer (...) podrá ser receptora o usuaria de las técnicas reguladas en la presente Ley". Las alusiones a la esterilidad y su tratamiento brillan por su ausencia. Cosa parecida ocurre con las mujeres que superan los márgenes cronológicos de la fertilidad femenina humana, pues, si bien deberá ser "mayor de 18 años y con plena capacidad de obrar", no se molesta la Ley en indicar su máximo, y valiosos ejemplos hay de su abuso. 
razones -desde las culturales y éticas, hasta las derivadas de la propia novedad tecnológica de estos medios de fecundación- puede resultar especialmente dificultoso obtener el material genético necesario para llevarlas a cabo" sí resume la raíz de la permisión. Con todo, se hace patente su crudeza. Se trata de limar las razones culturales, éticas y médicas que frenen la implantación del fenómeno, habida cuenta que las jurídicas ya se allanan con escasos miramientos en la propia Ley. Eso se parece mucho a las conductas inducidas. A mi juicio, el Derecho no sirve para el adoctrinamiento práctico, máxime cuando se hace a costa de principios inviolables en materia de filiación.

\section{A MODO DE CONCLUSIÓN}

A simple vista, existen tres datos francamente llamativos en el contraste que hemos hecho entre la decisión del Tribunal Supremo sobre el anonimato de la madre y la sentencia del Tribunal Constitucional español sobre el anonimato del donante de esperma.

Primero, el ámbito de las decisiones: una corresponde al órgano encargado del juicio de constitucionalidad de las leyes, mientras el Tribunal Supremo se circunscribe a decidir sobrevenidamente derogada una norma por oponerse a la Constitución, pero sin que le sea conferida dicha competencia en sus estrictos términos.

Segundo, la cronología: al menos resulta curioso que cuando el Tribunal Supremo formuló su idea existía ya dictada escasos meses antes otra del Tribunal Constitucional en opuesto sentido.

Tercero, los resultados prácticos: la madre, que contaba con medidas de apoyo en concretas situaciones que pudieran poner en riesgo la vida del hijo, las pierde; mientras el padre que, a partir de la reforma del año 1981, olvidó sus injustos privilegios anteriores, se ve beneficiado de la misma dispensa que ahora se niega para la madre.

Todo ello al amparo del principio de igualdad, cuyo respeto práctico queda reducido a ruina jurídica.

\section{BiBLIOGRAFÍA}

AlBaladejo, Manuel, El reconocimiento de la filiación natural, Bosch, Barcelona, 1954.

DURÁn RivaCoBA, Ramón, "Adopción por los abuelos maternos contra la voluntad del progenitor (Comentario a la Sentencia del Tribunal Supremo de 2 de marzo de 1989)", La Ley III, 1989.

"La eficacia del reconocimiento de la filiación extramatrimonial del menor o incapaz", Anuario de Derecho Civil, 1987. 
HeRnández Gil, Antonio, en Constitución española. Trabajos Parlamentarios, IV, Cortes Generales (editor), Madrid, 1980.

Quesada GonzÁlez, "Algunas reflexiones sobre la maternidad a principios del siglo XXI", en Estudios Jurídicos en Homenaje al Profesor Luis Díez-Picazo, III, Civitas, Madrid, 2003.

Ramos Chaparro, Enrique "La inconstitucionalidad sobrevenida del desconocimiento materno", en Estudios Jurídicos en Homenaje al Profesor Luis DíezPicazo, III, Civitas, Madrid, 2003.

RIVERO, Francisco, “¿Mater semper certa est? Problemas de la determinación de la maternidad en el ordenamiento español", en Anuario de Derecho Civil, 1997.

, "De nuevo sobre el derecho a conocer el propio origen. El asunto Odièvre (Sentencia del Tribunal Europeo de Derecho Humanos de 13 de febrero de 2003)", en Actualidad Civil № 2, 2003.

Rubio Torrano, Enrique "El secreto de la maternidad", Aranzadi Civil № 9, 2003. 
